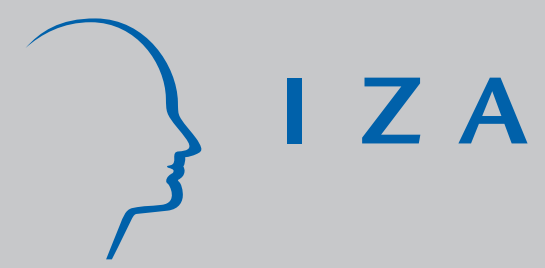

IZA DP No. 7878

Minimum Wages, Unemployment and Informality: Evidence from Panel Data on Russian Regions

Alexander Muravyev

Aleksey Oshchepkov

December 2013 


\title{
Minimum Wages, Unemployment and Informality: Evidence from Panel Data on Russian Regions
}

\author{
Alexander Muravyev \\ IZA and St. Petersburg University GSOM \\ Aleksey Oshchepkov \\ CLMS, Higher School of Economics (HSE), Moscow
}

Discussion Paper No. 7878

December 2013

\author{
IZA \\ P.O. Box 7240 \\ 53072 Bonn \\ Germany \\ Phone: +49-228-3894-0 \\ Fax: +49-228-3894-180 \\ E-mail: iza@iza.org
}

\begin{abstract}
Any opinions expressed here are those of the author(s) and not those of IZA. Research published in this series may include views on policy, but the institute itself takes no institutional policy positions. The IZA research network is committed to the IZA Guiding Principles of Research Integrity.

The Institute for the Study of Labor (IZA) in Bonn is a local and virtual international research center and a place of communication between science, politics and business. IZA is an independent nonprofit organization supported by Deutsche Post Foundation. The center is associated with the University of Bonn and offers a stimulating research environment through its international network, workshops and conferences, data service, project support, research visits and doctoral program. IZA engages in (i) original and internationally competitive research in all fields of labor economics, (ii) development of policy concepts, and (iii) dissemination of research results and concepts to the interested public.
\end{abstract}

IZA Discussion Papers often represent preliminary work and are circulated to encourage discussion. Citation of such a paper should account for its provisional character. A revised version may be available directly from the author. 


\section{ABSTRACT}

\section{Minimum Wages, Unemployment and Informality: Evidence from Panel Data on Russian Regions}

This paper revisits labor market effects of the minimum wage by taking advantage of a unique institutional setting and rich data from Russia that cover 89 regions over 10 years, from 2001 to 2010. Our empirical analysis draws on the methodology introduced by Neumark and Wascher, in which labor market outcomes at the regional level are related to the relative minimum wage (captured by the Kaitz index) in a panel setting. We find that the minimum wage raises unemployment among young workers aged 15 to 24 . In contrast, there is no evidence of disemployment effects of the minimum wage for workers aged 25-72, including women. In addition, minimum wage hikes are associated with an increase in informal employment.

JEL Classification: J38, J23

Keywords: $\quad$ minimum wages, unemployment, informal employment, Russia

Corresponding author:

Alexander Muravyev

IZA

P.O. Box 7240

53072 Bonn

Germany

E-mail: muravyev@iza.org

\footnotetext{
* The authors thank John Earle, Hartmut Lehmann, Francesco Pastore, Sergei Roshchin, and Fabian Slonimczyk for valuable comments and suggestions. They are also grateful to the Center for Labor Market Studies of the HSE, and in particular, its director Vladimir Gimpelson, as well as to Olga Olshchanskaya from the Federation of trade unions of Russia for facilitating access to the data. The paper has benefited from discussions at the 52nd European Congress of RSAI, Bratislava, August 2012, IZA-HSE workshop "Labor Market Adjustment in the Commonwealth of Independent States, Central Asia and China in the Wake of the Great Recession", Moscow, October 2012, XIV international conference "Public Sector Transition", St. Petersburg, November 2012, international conference "The Pacific Rim Economies: Institutions, Transition and Development", Seoul, April 2013 as well as HSE and IZA research seminars. Alexander Muravyev acknowledges financial support from Fritz Thyssen Foundation, research project "Risk Attitudes and Labor Market Informality, with a Case Study of Russia". Aleksey Oshchepkov acknowledges financial support from HSE Academic Fund Program, research grant No 11-01-0028.
} 


\section{Introduction}

The minimum wage remains one of the most controversial issues in labor economics, economic policy, and politics. Introduced with the goal of promoting income equity and reducing poverty, the minimum wage has been criticized for its potential adverse effects on the labor market. Much of the criticism has been based on the standard labor supply and demand model, which suggests that the minimum wage raises unemployment, especially among low skilled workers (Stigler 1946). Rather than help low-wage earners, in the competitive labor market the minimum wage does exactly the opposite.

It is well known, however, that the standard perfect competition model may not adequately describe labor markets, which invalidates its predictions regarding the minimum wage. For example, in the presence of monopsony in the labor market, which, as shown in Ashenfelter, Farber and Ransom (2010) and Manning (2011) is a widespread phenomenon, introducing minimum wages may not only increase the wages of low-skilled workers, but also raise overall employment (see e.g., Boal and Ransom 1997). Recent theoretical extensions of the debate include Cahuc and Laroque (2009) and Danziger (2010), who question the benefits of the minimum wage in monopsonistic environments, Strobl and Walsh (2011), who stress the distinction between the intensive and extensive margins of labor market adjustment, and Lee and Saez (2012), who show that a binding minimum wage, despite negative effects on employment, may nevertheless be a viable policy option for governments that value redistribution towards low wage workers.

The empirical evidence of labor market effects of the minimum wage remains inconclusive. Although Neumark and Wascher (2008), the most comprehensive survey of the relevant literature up to 2006, concludes that the minimum wage has a negative effect on the employment opportunities of less-skilled workers with no effect on the overall employment, several recent contributions show that the debate is far from being over. For example, Dube, Lester and Reich (2010) find no disemployment effects in restaurants and other low-wage sectors in the US. Dolton, Rosazza-Bondibene and Wadsworth (2012) report no or a small positive impact of the minimum wage on employment in the UK. However, Sen, Rybczynski and Van De Waal (2011) find significant disemployment effects among teens in Canada. The lack of accord is accompanied by discussion regarding the appropriateness of different methodological approaches, such as time-series regressions, case studies, and state panel data regression analysis (see Bazen and Le Gallo 2009; Dube at al. 2010). An interesting recent contribution to this debate is Neumark, Salas and Wascher (2013). 
The pros and cons of the minimum wage are subject to even greater controversy in the context of developing and emerging economies, which are characterized, as a rule, by a greater incidence of low wage work, widespread employment in the informal sector, and generally poor enforcement of laws and regulations (e.g., Bhorat, Kanbur and Mayet 2012). An aspect that draws particular attention of scholars is the effect of the minimum wage on informality in the labor market (see Nataraj et al. 2013). This latter issue is also relevant, albeit often neglected, in the context of developed economies (Williams and Windebank 2012). Indeed, as noted by Schneider (2010), "shadow economies are a complex phenomenon present to a large extent in all type of economies (developing, transition, and highly developed)".

The standard dual economy models of labor market segmentation suggest that an increase in the minimum wage will drive the least productive workers from the formal sector into the informal one, resulting in falling wages in the informal sector. Empirical evidence, however, is mixed. Regarding formal and informal employment, many studies find increasing informalization as a result of minimum wage hikes (e.g., Carniero 2004 for Brazil, Comolo and Mello for Indonesia, and Amin 2009 for India), with ambiguous aggregate employment effects. Some studies, such as Lemos (2009), find no evidence of adverse employment effects for either the formal or informal sector. In contrast, Magruder (2013) shows, with the example of Indonesia, that introducing minimum wages may have a big push effect on the economy, resulting in the expansion of formal employment and contraction of the informal sector. Regarding wages, most empirical studies document a theoretically counterintuitive increase of wages in the informal sector following minimum wage hikes, known as the lighthouse effect (e.g., Boeri et al. 2011; Khamis 2013).

This paper revisits the effect of the minimum wage on employment using rich regional-level data from Russia that span 89 regions and 40 quarters between 2001 and 2010. There were eight increases in the federal minimum wage during this period, two of which (by about 100 percent) were almost unprecedented among not only developed, but also developing countries. Additional variation in the data stems from the decentralization of the minimum wage setting in September 2007, which gave the regions of Russia the power to set their own regional minima above the federal floor.

Our analysis draws on the methodology introduced by Neumark and Wascher in 1992 which in subsequent years has become standard in empirical studies of the minimum wage (e.g., Zavodny 2000; Lemos 2009; Addison and Ozturk 2012). In particular, we relate various labor market outcomes at the regional level to the relative minimum wage (captured by the 
Kaitz index ${ }^{1}$ ) in a panel setting. The data on regional labor markets come from Russia's Labor Force Survey (LFS) and other sources available from the Russian Statistical Agency (Rosstat). These are complimented with detailed data on federal and regional minimum wages collected by us.

The main strength of the paper is the use, for identification purposes, of the unique data with extremely large variation in the minimum wage as well as in labor market outcomes across 89 regions of Russia over 10 years. To our best knowledge, our study is the first that exploits this quasi-experimental setting in the analysis of labor market effects of the minimum wage. $^{2}$ Second, our data from post-transitional Russia, a country that combines essential features of developed and developing economies, are very well suited for studying a broad range of labor market outcomes, including not only unemployment among various sub-groups in the population, but also informal employment. Third, in contrast to many studies that focus on instantaneous effects of the minimum wage, we consider a more flexible estimation framework that allows for both advances and delays in the reaction of the labor market on minimum wage hikes. Last but not least, our study can be viewed as an indirect robustness test for the US results by Neumark and Wascher using a different setting.

Our results suggest an adverse effect of the minimum wage on young workers in the form of higher unemployment among those aged 16 to 24. In contrasts, we find no evidence of disemployment effects of the minimum wage for workers aged 25 to 72 . These results are in line with the bulk of the previous empirical literature that suggests significant negative consequences of the minimum wage for most vulnerable groups in the labor market, but insignificant effects for the working age population in general. Another result of our study is related to the effect of minimum wages on informal employment. We find that minimum wage hikes lead to an increase in the share of workers employed in the informal sector. This may imply relocation of workers from the formal sector to the informal one as a consequence of minimum wage increases, which is consistent with the observed high inter-sectoral mobility (e.g., Bosh and Maloney, 2010; Lehmann et al., 2012). These findings, therefore, cast doubt on the effectiveness of minimum wages in promoting income equity and reducing

\footnotetext{
${ }^{1}$ The Kaitz index is the ratio of the minimum wage to the average wage.

${ }^{2}$ Two related papers are Kobzar (2009) and Lukiyanova (2011). The former study discusses changes in the minimum wage during the last decade and attempts to evaluate their effect on regional labor markets. The empirical analysis yields no statistically significant results, perhaps, due to methodological limitations, such as the use of annual data, which is very problematic in the rapidly changing and highly volatile economic environment of Russia. The second paper only deals with the distributional effects of the minimum wage among those employed. It suggests that minimum wage hikes can result in the decline in the lower tail inequality, particularly for females. Potential disemployment effects of the minimum wage are not considered in the study.
} 
poverty since informality, at least in the wage employment sector, is typically associated with lower job security, lower earnings, and the lack of social security protection.

The rest of the paper is organized as follows. Section 2 provides the institutional background of minimum wage setting in Russia. Section 3 describes the data. Section 4 outlines the methodology of our empirical analysis. Section 5 presents and discusses the empirical results. Section 6 concludes.

\section{Institutional background}

The minimum wage in Russia is not a new phenomenon as it existed already during the central planning era. In 1985, for example, the minimum wage amounted to 70 Rubles, which, given the average wage in the country (about 190 Rubles), implied a Kaitz index of about 37 percent. The Kaitz index in the USSR was thus similar to what is now observed in many OECD economies. In the 1990s, a period of economic reforms accompanied by hyperinflation, there was a dramatic erosion of the real minimum wage in Russia, despite regular minimum wage hikes (see Chart 1). As a result, by the start of the new century, the minimum wage amounted to a mere 6-7 percent of the average wage. ${ }^{3}$ A number of more substantial increases were introduced between 2001 and 2007 but, given double-digit inflation in the country, they only helped to keep the Kaitz index at about 10 percent. Starting in 2007, a number of large increases in the minimum were legislated. For example, the nominal minimum wage was raised by 109 percent in September 2007 and 88 percent in January 2009. These increases brought the Kaitz index well above 20 percent. $^{4}$

The regulatory framework for the minimum wage is established in Russia's Labor Code. The country has a nationwide (federal) minimum wage as well as regional minimum wages (since 2007). ${ }^{5}$ The federal minimum applies to all groups of workers, without any differences by age, occupation or industry. Since September 2007, regions have the right to define their own regional minima (which may be sector-specific) above the federal threshold. Many regions quickly took advantage of this opportunity (see Chart 2), which resulted in the substantial spatial differentiation of the nominal minimum wage by 2008. Interestingly, the apparent enthusiasm of the regional governments in setting their own minimum wages was

\footnotetext{
${ }^{3}$ This remarkable decline in the minimum wage drew attention of some scholars already in the 1990s, e.g. Brainerd (1998).

${ }^{4}$ These hikes are almost unprecedented among not only developed, but also developing countries. We are aware of only two increases in the minimum wage which are similar in magnitude to Russia's. One took place in Hungary in 2001 (Kertesi and Kollo, 2003) and the other one occurred in Indonesia in 1990s (Rama, 2001). In the latter case the doubling of the minimum wage took four years.

${ }^{5}$ Russia is federation of 83 territories or "subjects of Federation". Before the wave of mergers which was launched in 2005 the number of regions was 89.
} 
short-lived: after the 2008 financial crisis few regions legislated their own minima and the 2009 increase of the federal minimum wage overshot most regional thresholds established in 2007-2008.

One additional aspect to studying minimum wages in Russia is related to the so-called Northern wage multiplier, inherited by Russia from the USSR. In the state-controlled economy of the USSR, workers living in the North and Far East were entitled by law to higher wages (including higher minimum wages), introduced via the Northern multiplier, which varied from 1.15 to 2 depending on the severity of living conditions in the respective territories. ${ }^{6}$ While the privatization process of the 1990s made this system no longer applicable to the wage setting in most of the economy, it remained binding for the minimum wage in both private and public sectors until August 2007. The Northern multiplier thus implied a substantial cross-regional variation in the nominal minimum wage in Russia. ${ }^{7}$

The 2007 decentralization of the minimum wage setting eliminated the link between the minimum wage and the Northern multiplier, previously set in federal law. This change generated additional variation in the minimum wage. In particular, while most regions of Central Russia saw in September 2007 an increase in the nominal minimum wage by 109 percent, from 1,100 Rubles to 2,300 Rubles, some Northern territories which did not legislate their own regional minima saw only a tiny increase of 5 percent. Indeed, in these regions the minimum wage rose from 2,200 Rubles before September 2007 (the federal minimum of 1,100 Rubles times the Northern miltiplier of 2) to 2,300 Rubles after September 2007 (the new federal minimum).

So far we have focused on the variation in the nominal minimum wage. However, in the Russian context it is equally or even more important to consider the cross-sectional and timeseries variation of the relative minimum wage, expressed as the Kaitz index. Substantial cross-regional variation in the Kaitz index existed in most parts of the country (those not covered by the Northern wage multiplier) even before the 2007 decentralization of the nominal minimum wage. This is due to the enormous differences in the average wage (and wage distribution in general) across the regions of Russia. For example, in November 2005, the lowest and highest average regional wages amounted to 5,100 and 30,324 Rubles, and the

\footnotetext{
${ }^{6}$ For example, in Chukotka, the region in the Russian North-East bordering Alaska of the US over the Bering strait, the multiplier was equal to 2; in the Murmansk region, which borders Finland and Norway to the West and has a much milder climate than Chukotka, the multiplier was equal to 1.4.

${ }^{7}$ The Northern multiplier could also vary by districts within large regions. For example, while in most of the Republic of Karelia, which borders Finland to the West, the multiplier was equal to 1.15, in its Northern parts it was set at the level of 1.4.Due to the lack of district-level data, we do not explore this inter-regional variation in the minimum wage in the analysis that follows, but adjust our regional-level data on minimum wages using the shares of the population living in districts with different wage multipliers.
} 
P90/10 decile ratio of the average regional wage was 3.87. As a result, the Kaitz index varied across the regions from below 5 percent to about 20 percent (see Table 1). Despite the trend of convergence among Russian regions over the last decade (Guriev and Vakulenko 2012), including in terms of wages and other labor market outcomes, substantial differences in relative minimum wages remained across the regions, due to the variation in both nominal minimum wages and average wages. For example, as shown on Chart 3 , the maximum level of the Kaitz index was above 50 percent, and the minimum level was below 10 percent in 2009.

Chart 3 also suggests a relatively quick erosion of the real minimum wage between the adjacent hikes. This is due to the high inflation typical of Russia of the early 2000s. Indeed, during the period under study, Russia saw double digit inflation except for three years: 2006 (9.0\%), 2009 and 2010 (8.8\% each year). This fact will be important for the discussion of possible delays in the reaction of the labor market to minimum wage hikes.

Several regions have specific regulations concerning coverage of the regional minimum wage. Regional minima, set above the federal floor, can apply to the private sector workers and/or to the public sector workers who are employed by regional governments. Most common, however, is the case when the regional minimum wage only covers the private sector, while the public sector is subject to the federal minimum wage. There are also instances when the regional minimum wage is linked to the regional subsistence level and is automatically reviewed several times per year. Because such instances are rare, we do not provide a detailed overview here. However, we document these cases in the data and control for them in the empirical analysis that follows.

One additional aspect that has implications for our analysis is that most hikes of the minimum wage at the federal level were introduced rather unexpectedly or, at least, following only a short discussion. For example, the increase on October 1, 2003 from 450 Rubles to 600 Rubles was passed by the State Duma (the lower chamber of Russia's parliament) on September 17, 2003, approved by the Federation Council (the upper chamber of the parliament) on September 24, 2003, and signed by the President on October 1, 2003. Similarly, the increase on January 01, 2005 was passed by the State Duma on December 17, approved by the Federation Council on December 24, and signed by the President on December $29,2004 .^{8}$ The same was typical of regional laws on minimum wages. Here, the situation is even more extreme because there were several instances of retroactive changes in

\footnotetext{
${ }^{8}$ This is, however, not true of the two most substantial hikes in the federal minimum wage in September 2007 and January 2009. In the former case, the respective law was signed by President on April 20, 2007, and in the latter case - on June 28, 2008
} 
the minimum wage. For example, in November 2007 the Vologda region raised the local minimum to 3,300 Rubles (43.5\% above the level stipulated in federal law, which was 2,300 Rubles at the time), and this change was introduced retroactively from September 01, 2007. Similarly, the elevation of the minimum wage in St. Petersburg to 6,200 Rubles (43.2 percent above the federal minimum, which was 4,330 Rubles) from January 01, 2009 was introduced by the local government retroactively on February 13, 2009. An important implication is that firms were in most cases restricted in the opportunity to adjust employment levels in advance, before minimum wage hikes taking effect.

\section{Data}

The dataset used in this paper was assembled from several principal sources. Its key component is the data on nominal minimum wages. As the minimum wage was set at the federal level up to September 2007, the collection of the necessary time-series for January 2001 - August 2007 was quite straightforward. The data were taken from the respective federal laws. We adjusted these data using the Northern wage multiplier that was in force until September $2007 .{ }^{9}$ For regions with different multipliers applicable to different districts, we computed the average Northern multiplier using district population as weights (see footnote 7).

Assembling data on regional minimum wages was less straightforward. The key source of data was information collected by the Federation of trade unions of Russia kindly provided to us by its Moscow office. This source, however, contains data with semi-annual frequency only. Moreover, it does not have all the necessary details concerning the coverage of the regional minima. Therefore, in addition to this source we conducted our own study of regional legislation on minimum wages for each subject of the Federation. The information was taken from databases of national and regional laws, such as Konsultant Plus, as well as from web-sites of regional governments and other sources in the Internet. We paid particular attention to the coverage issue. We also marked all unclear or problematic cases, related, for example, to retroactive enactment of minimum wages or uncertainties arising when the regional minimum wage is linked to the subsistence minimum. All these instances were documented and marked in the database with dummy variables. Overall, we assembled a complete time series of minimum wages in all Russian regions over 10 years, from January 2001 to December 2010.

\footnotetext{
${ }^{9}$ We rely on the list of Northern territories of November 10, 1967 adopted by the Council of Ministers of the USSR with numerous changes and adjustments since then.
} 
These data were supplemented with information from the Russian Statistical Agency (Rosstat) on the average wage, unemployment, including among the youth, as well as informal employment in each region. Most of these data are available on the quarterly basis. In particular, we consulted the Labor Force Survey (LFS), which is conducted by Rosstat on February, May, August and November each year. ${ }^{10}$ The LFS covers all regions of Russia and contains several hundred thousand observations. Importantly, the survey is representative on the regional level. It provides a wealth of information regarding the national and local labor markets. In particular, it allows the classification of the population into employed and unemployed based on ILO definitions, and contains a rich set of questions on informal employment.

With these data at hand, we were able to compute the following six dependent variables measuring, on the quarterly basis, labor market outcomes in Russian regions:

- Unemployment rate (UNEMPL_15_72), defined as the number of unemployed divided by the economically active population aged 15-72. As is standard in labor market statistics, the economically active population consists of employed and unemployed people.

- Unemployment rate (UNEMPL_25_72), defined as the number of unemployed divided by the economically active population aged 25-72.

- Youth unemployment rate (UNEMPL_15_24), same as the general unemployment rate, but calculated for those aged 15-24.

- Female unemployment (FEMALE_UNEMPL), defined as the number of unemployed women divided by the number of economically active women aged 25-72.

- Informal employment rate (indicator 1, INFORML_A) is the share of the employed whose main job is in the informal sector. ${ }^{11}$

- Informal employment rate (indicator 2, INFORML_B) is the share of the employed whose main or second job is in the informal sector.

\footnotetext{
${ }^{10}$ These are not open-access data, but they were made available to us through the Center for Labor Market Studies at the HSE Moscow. The official link to the survey on the Rosstat's web-site:

http://www.gks.ru/wps/wcm/connect/rosstat_main/rosstat/ru/statistics/publications/catalog/doc_1140097038766.

${ }^{11}$ Our definition of informal work follows the Rosstat approach. It considers all workers whose job is not within a firm to be informal. An important advantage of such a general definition of informality is that it is not sensitive to mistakes and non-responses of respondents when questions about the size of the firm, its official status (registered vs. unregistered), contributions to the social security funds, etc. are asked. But the advantage can also turn out to be a deficiency. In particular, it is possible that the definition omits some other important manifestations of informal employment, especially informal employment within the formal sector. The available evidence from Rosstat, however, suggests that such employment constitutes only about $1 \%$ of all informal employment. We therefore believe that the measure of informal employment available to us is reasonably accurate and captures most essential aspects of this phenomenon in Russia.
} 
One difficulty in our empirical analysis stems from the lack of wage data in the Russian LFS. Because of that, we took information on average wages across the regions of Russia from the annual yearbook by Rosstat "Socio-economic situation of Russia" (Rosstat, various years). This information, combined with our hand-collected data on minimum wages, makes it possible to compute regional Kaitz indices for February, May, August and November of each year between 2001 and 2010. From Rosstat we also obtained additional information, such as changes in industrial production on the regional level. ${ }^{12}$

The descriptive statistics of the data are shown in Table 2. Panel A provides details for the entire dataset, spanning 2001-2010, Panel B shows the statistics for the subset of the data that covers 2001-2006 (when the main source of the variation in minimum wages was federal laws), and Panel C describes the 2007-2010 subset (when a substantial part of the variation in minimum wages stemmed from regional laws). During the entire period under study, the Kaitz index varied from three percent to above 50 percent, with the average value being about 18 percent. For the 2001-2006 subset, the Kaitz index averaged 12.6 percent compared to about 26 percent for the 2007-2010 subset. The data also show considerable variation, both over time and across space, in key labor market variables. The unemployment rate, while averaging nine percent across all regions and all quarters (UNEMPL_15_72, unweighted data), varies from one percent to 54 percent. Youth unemployment averages 17 percent, but varies a great deal across the regions and over time. The share of informal workers is 17 or 20 percent (depending on the definition used) with large variation across regions and over time.

\section{Methodology}

Our empirical approach draws on the methodology developed by Neumark and Wascher (1992) for US state-level panel data analysis of the minimum wage. ${ }^{13}$ In this methodology, the dependent variable, most often the unemployment rate among the youth, is regressed on either the level of the (regional) minimum wage or the respective Kaitz index. Variations of these two approaches include controlling for the average wage (in the first type of specifications) and introducing regional price levels (see Neumark and Wascher 2008 for a review).

\footnotetext{
${ }^{12}$ The change in industrial production over the previous four quarters is captured by variable OUTPUT_CH. Additional variables collected by us and used in the empirical analysis include: SUBS_MIN, a dummy for regional minimum wages being linked to respective subsistence minima, COVERAGE, a dummy for incomplete coverage of the regional minimum wage, DATA_DISC, a dummy for discrepancies among different data sources on regional minimum wages, and ADV, a dummy for early announcement of the minimum wage increase (at least, one quarter in advance).

${ }^{13}$ Other approaches include time-series analysis (Brown, Gilroy and Kohen 1982) and a case study (Katz and Krueger 1992; Card and Krueger 1994).
} 
Given the relatively high inflation in Russia during the period under study as well as potential issues with reliability of regional price data, we opt for the approach based on the Kaitz index. ${ }^{14}$ For the purpose of this analysis we introduce a slight adjustment to the classical definition of the Kaitz index. Specifically, we use a lagged value of the average wage in the denominator of the usual formula:

$$
\text { Kaitz }_{t}=M W_{t} / A W_{t-1},
$$

where $M W$ stands for the minimum wage, $A W$ denotes the average wage, and $t$ denotes quarters. The use of the lagged value in the denominator excludes the effect of minimum wage hikes on the average wage. Indeed, the contemporaneous average wage incorporates the effect of a minimum wage increase: some low-wage earners get fired and the wages of those remaining employed get adjusted. This, ceteris paribus, underestimates the true change in the Kaitz index between the time of the minimum wage increase and the preceding period. However, the results with the standard Kaitz index, which is based on using the contemporaneous average wage in the denominator, $\mathrm{Kaitz}_{t}=M W_{t} / A W_{t}$, turn out to be similar to our benchmark results with $\mathrm{Kaitz}_{t}=M W_{t} / A W_{t-1}$.

Our baseline specification takes the following form:

$$
L M O_{i t}=\alpha_{i}+\beta_{1} \text { Kaitz }_{i t}+\boldsymbol{X}_{i t} \boldsymbol{\gamma}+\delta_{t}+\varepsilon_{i t,}
$$

where subscripts $i$ and $t$ index regions and time respectively, $L M O_{i t}$ is a labor market outcome, such as the general or youth unemployment rate, $\alpha_{i}$ is a regional fixed effect capturing time invariant unobserved characteristics of regions, Kait $z_{i t}$ is the Kaitz index as defined above, $\boldsymbol{X}_{i t}$ is a vector of control variables (characterizing the coverage of the minimum wage, its connection to the subsistence minimum, etc.), $\delta_{t}$ is a time effect capturing macroeconomic shocks common to all regions, and $\varepsilon_{i t}$ is a random disturbance. Index $i$ varies from 1 to 89 (the number of regions in Russia in the early 2000s). Index $t$ spans 10 years and four quarters. ${ }^{15}$ The parameter of interest is $\beta_{1}$, which shows the effect of the minimum wage on the labor market outcome chosen.

As already noted in Section 2, many increases of the minimum wage at the federal level were introduced without advanced notice. On the regional level, there were instances of

\footnotetext{
${ }^{14}$ In Russia, this index is highly correlated with another common measure of the effectiveness of the minimum wage, the so-called "fraction affected" (the share of workers with wages above the current minimum wage, but below the future minimum wage), which in our data can be computed for some years. The cross-regional correlations between the fraction affected and monthly Kaitz index are high, ranging from 0.7 to 0.9. Due to the irregular nature of the data on wage distribution (which were only collected by Rosstat in April of some years) we do not use the "fraction affected" in the analysis that follows.

${ }^{15}$ Thus, we control for the year and quarter of each observation using nine annual and three quarterly dummies. This approach addresses seasonality issues. The alternative approach with interactions of annual and quarterly dummies gives similar results. The first approach is preferred as leading to a more parsimonious model, with fewer parameters to be estimated.
} 
retroactive changes in the minimum wage. The unexpected nature of minimum wage increases implies that advance reaction of employers on (anticipated) changes in minimum wage laws is unlikely. Moreover, as the notification period for non-disciplinary firings in Russia is two months (and three months for collective dismissals, see OECD 2013), the labor market may not react to changes in minimum wages instantaneously, in the quarter of the minimum wage hike. Rather, the adjustment may come with a delay of several months. From the modeling viewpoint, this calls for using lagged values of the minimum wage or Kaitz index on the right hand side of the regression, in the form of a distributed lag model.

In this context, the optimal number of lags becomes an issue. There are good reasons to believe that the number of lags should not be too large. The key factor is the relatively high inflation in Russia, which fairly quickly erodes real minimum wages. The implication is that, several quarters after an increase, the relative minimum wage effectively returns to the preincrease level, reducing employers' incentives to adjust the level of employment. Based on these considerations, we extend our baseline model by adding one to four lags of the Kaitz index. In the case of two lags, the model transforms into:

$L M O_{i t}=\alpha_{i}+\beta_{1}$ Kaitz $_{i t}+\beta_{2}$ Kaitz $_{i t-1}+\beta_{3}$ Kaitz $_{i t-2}+\boldsymbol{X}_{i t} \boldsymbol{\gamma}+\delta_{t}+\varepsilon_{i t .}$

We test for the optimal number of lags using the standard AIC and BIC criteria. ${ }^{16}$

Although an advanced adjustment of the labor market to minimum wage hikes seems to be unlikely in Russia, we formally test for it by introducing a lead-and-lag structure to the model (with one leading regressor). This is done in two steps. First, we add a simple leading regressor to the baseline specification. Second, we interact the leading regressor with a dummy variable for early announcement (at least one quarter before the actual change) of the minimum wage change. The leading regressor is thus set to zero in the case of sudden enactment of a new minimum wage.

We then consider a battery of additional regressions that help test the robustness of our results. In particular, we exclude regions where the Northern wage coefficients applied. We also drop regions with very strong labor markets (Moscow city, Moscow region, and St. Petersburg city) as well as with very weak ones (the republics of Daghestan, Ingushetia, and Tyva). We also re-estimate the regressions using the population weights (given the huge variation in the size of the regions, this approach helps estimate the effect of the minimum wage on the economy at large). Then we conduct separate analyses using data from 20012006 (federal increases in the minimum wage) and from 2007-2010 (predominantly regional increases in the minimum wage). The data from the latter period are of particular interest not

\footnotetext{
${ }^{16}$ Looking ahead, the optimal number of lags is equal to one in most specifications.
} 
only because of considerably larger variation across regions, but also because of desynchronized changes in the minimum wage. The latter facilitate econometric identification when time fixed effects are incorporated in the model. Finally, we experiment with additional controls, the change in industrial production being the most prominent example.

As indicated in equations (2) and (3), our models are two-way fixed effects models which we estimate using Stata by specifying region fixed effects and introducing a set of dummies for years and quarters. As regards inference, we rely on the cluster robust estimator of variance with clustering by regions. This takes care of potential violations of the assumption that standard errors $\varepsilon_{i t}$ are independently and identically distributed. In particular, it ensures that the standard errors are correct when observations are independent across regions, but not necessarily within regions.

\section{Empirical results}

\subsection{Results for the full dataset, 2001-2010}

We start with the baseline specification estimated using full data from 2001 to 2010 but with different numbers of lags (which may capture delayed reaction of the labor market on changes in the minimum wage) and also allowing for one leading regressor (which may capture advance reaction of the labor market). In order to be able to compare models with different number of lags and leads using the conventional information criteria AIC and BIC, the number of observations is set the same in all regressions, 2686 (as in the model with four lagged regressors and one leading regressor). Table 3 (Panel A and Panel B) summarizes the results. The columns of the table correspond to the dependent variable chosen. The rows correspond to different sets of regressions.

At the top of Panel A, we report the first set of results for regressions with no lag structure. Beneath these results, we provide estimates for regressions with one lag. Proceeding in the same fashion, we end up with regressions containing four lags. Note that for the reasons of space the table only shows the key coefficients of interest (on the relative minimum wage variable measured by the Kaitz index and its lags) as well as R-squared. The extensive set of time dummies as well as other controls, which are included in the regressions, are not reported in the table.

Since the main purpose of the regressions in Table 3 is to provide evidence on the appropriate number of lags in the estimation, we discuss the table by blocks of results (horizontally) rather than by dependent variables (vertically). The first set of results shows no 
effect of the contemporaneous relative minimum wage on all labor market outcomes chosen. The coefficients are insignificant both economically and statistically.

The second block of results, for the regressions with one lag of the Kaitz index, shows fairly large coefficients on the lagged value in the regressions with unemployment rate (among workers aged 15 to 72 ) and youth unemployment rate as dependent variables (columns 1 and 3, respectively). In the former regression, the coefficient on the lagged Kaitz is statistically significant at the ten percent level. In the latter regression, the coefficient is statistically significant at the one percent level. The signs and magnitudes of the estimated coefficients are plausible. Higher relative minimum wages result in disemployment effects. In particular, an increase in the Kaitz ratio by one percentage point leads to an increase in the unemployment rate (among workers aged between 15 and 72) of 0.031 percentage points and in the youth unemployment rate by 0.120 percentage points. Interestingly, for workers aged 25 to 72 we observe no disemployment effect of the minimum wage. This suggest that the significant coefficient on the Kaitz index in the regression based on the sample of workers aged 15 to 72 is driven by young workers. Finally, we observe a positive effect of the minimum wage on informal employment, which is statistically significant at the five percent level for one of the two measures of informality chosen (column 5).

The next set of results, which is based on the model with two lags, suggests a similar pattern. A higher Kaitz index is associated with higher youth unemployment, with the effects appearing one quarter after the minimum wage hike (column 3). In addition, there is a positive and statistically significant coefficient on the first lag of the Kaitz index in the models with informal employment as the dependent variable (columns 5 and 6). The effect of the minimum wage on unemployment among those aged 15-72 is no longer statistically significant. Importantly, the second lag of the Kaitz index is never statistically significant. This is largely consistent with the discussion of the Russian labor market and minimum wage laws in Section 2, which suggested delays, albeit not very long, in the reaction of employers to minimum wage changes.

The last two sets of results in Panel A, for the model with three and four lags, support the idea that the delay does not exceed one quarter. In particular, the $3^{\text {rd }}$ and $4^{\text {th }}$ lags are insignificant in the overwhelming majority of specifications.

At the foot of Panel A, we provide the results of testing for the number of lags using the standard criteria AIC and BIC. The former criterion suggests zero to three lags, while the latter one suggests either one lag or no lags at all. The two criteria are in accord with each other in only two out of six cases (for two dependent variables only). Overall, we interpret all 
these results as supporting the specification with one lagged regressor. From now one, this will be our preferred specification.

Next, Panel B extends the analysis by adding a leading regressor to the model with one lag of the Kaitz index. The results are shown at the top of Panel B. The coefficients on the leading regressor are insignificant, both economically and statistically, in all regressions. The LR test that compares the extended model (containing a leading regressor) and the parsimonious model (without a leading regressor) favors the latter. The inclusion of a leading regressor does not change the key results (positive and statistically significant coefficients on youth unemployment and informal employment) reported in Panel A.

Finally, we modify the extended model to take into account the unexpected nature of many changes in the minimum wage in Russia. As discussed in Section 2, several hikes were introduced very quickly, which virtually rules out any advance reaction by employers. We therefore interact the leading regressor with a dummy for advance announcement (at least one quarter before the new minimum wage taking effect) of changes in the minimum wage policy. The results are shown at the foot of Panel B. Even in this specification, there is no evidence of advance reaction of the labor market on minimum wage hikes. We conclude that specifications with a leading regressor find no support in the data.

Next we study the robustness of the main results reported in Table 3, namely the positive association of the minimum wage with youth unemployment and informality. For that purpose we impose three restrictions on the sample and also introduce weights in the estimation. In particular, we sequentially exclude from the data the so-called Northern regions, regions with strong labor markets, and regions with weak labor markets that were defined in Section 4. The weights allow us to take into account huge differences in the size of Russian regions and to estimate the effect of the minimum wage on the economy at large.

The results are shown in Table 4. As before, the columns of the table correspond to the dependent variable chosen. The rows correspond to particular sub-samples. The first block of regressions in Table 4 shows results that are similar to those reported in Table 3 Panel A for the model with one lagged regressor. The only difference between these two regressions is the number of observations. Since in Table 4 we no longer compare models with different numbers of lags, we take advantage of additional observations relative to the regressions in Table 3. As in Table 3 Panel A, we observe positive and statistically significant coefficients on the lagged Kaitz index in the regressions with youth unemployment and informal employment (regardless of how it is measured) as the dependent variables. There is also a 
positive and statistically significant effect of the minimum wage on the unemployment rate among workers aged 15-72, albeit not on the unemployment rate among those aged 25-72.

The second block of results corresponds to the sub-sample that excludes the Northern regions. The results are similar to those discussed above. There are positive and large coefficients on the lagged Kaint index in the regressions with youth unemployment and informal employment, albeit in the latter case the coefficient lacks statistical significance.

The third block of results is based on the sub-sample that excludes regions with strong labor markets. There are only small changes in the magnitudes of the estimated coefficients as compared with the baseline model shown at the top of Table 4. Higher minimum wages are again associated with higher informal employment and higher unemployment among the youth.

Next, we drop from the sample regions with weak labor markets. The results stay qualitatively the same as above. The minimum wage is associated with youth unemployment and informal employment. These results are significant both statistically and economically. One percentage point increase in the minimum wage is associated with 0.11 percentage points increase in youth unemployment and 0.08 percentage points increase in informal employment.

Finally, we check whether our key results are sensitive to introducing weights that capture different sizes of Russian regions in terms of population. In particular, while several regions have over 5 million inhabitants, some have less than 0.25 million people. The results, which are reported at the foot of Table 4, confirm the previously reported pattern. Minimum wage hikes increase informal employment and youth unemployment. We conclude that our main findings survive a battery of robustness checks.

Overall, our findings are consistent with many previous studies, for both developed and developing economies, that document poorer employment prospects for unskilled workers and youth as well as higher incidence of informal work as a result of minimum wage hikes (e.g., Neumark and Wascher 2008, Nataraj et al. 2013). The lack of statistically and economically significant results for female unemployment in our analysis is also largely consistent with the previous studies. In general, the evidence regarding female employment and unemployment is controversial and inconclusive. For example, using a panel of 16 OECD countries over 1970-2008, Addison and Ozturk (2012) find lower female employment and participation rates, albeit less transparent results for female unemployment, as a consequence of minimum wage hikes. In contrast, Comola and de Mello (2011) report an attenuated effect of minimum wages on female employment. As summarized in Nararaj et al. (2013, p.16), "the effects of labor regulations on employment among women versus men are ambiguous". 


\subsection{Results for the 2001-2006 and 2007-2010 subsets of the data}

Given the dramatic change in the minimum wage setting in 2007 (the introduction of regional minima), we split the data into two subsets, one covering the years 2001 to 2006 and the other one covering the years 2007 to 2010, and analyze these two subsets separately.

For space reasons we do not discuss in detail the analysis of the optimal lead and lag structure for these two subsets of the data. The respective results can be found in the Appendix, Table A1 for the 2001-2006 subset and Table A2 for the 2007-2010 subset of the data. Similarly to the case of the full data, there is evidence of a delayed reaction of the labor market to minimum wage hikes, especially for the 2007-2010 subset. As before, there is little evidence of advance adjustment of the labor market following the announcements of minimum wage hikes. We therefore proceed with the specification that includes a contemporaneous Kaitz index as well as its lagged value.

The main results for the 2001-2006 subset are shown in Table 5. They are organized in the same way as the results for the entire dataset reported in Table 4. In this analysis, the only result that seems to be strong and robust enough is the positive association of the minimum wage with youth unemployment. The other coefficients are insignificant statistically and (in most instances) also economically. In particular, there is no evidence in the 2001-2006 data that minimum wage hikes lead to higher informal employment.

Table 6 shows the estimates for the second subset of the data, covering the years 2007 to 2010. The results are considerably stronger than for the 2001-2006 subset and are qualitatively similar to what we have found for the full data. In particular, there is strong evidence that minimum wage hikes lead to higher unemployment among the youth as well as to higher informal employment. As in the analysis of the entire dataset, the reaction of the labor market comes with a delay of one quarter. These findings are robust to the variations in the sample that we discussed in Section 4. They are also robust to the use of population weights in the estimation. Finally, for this subset of the data we add an extra control variable measuring change in industrial output during the four preceding quarters. The results are shown at the foot of Table 6. They appear to be qualitatively similar to our previous findings. The minimum wage adversely affects young workers and increases informality in the labor market. As regards the new control variable, it has the expected negative sign in the regressions with unemployment rates, although only in the case of youth unemployment the relevant coefficient is statistically significant. 
The analysis in this section reveals considerable differences in the results for the 20012006 and 2007-2010 subsets of the data. In general, the results for the former period appear to be much weaker than for the latter period. In contrast to 2007-2010, in 2001-2006 we observe essentially no effect of the minimum wage on informal employment. These differences may be attributed to various factors, from changes in the Russian labor market during the 10 years under study to changes in the nature of the minimum wage setting. As regards the former, there is, for example, evidence of increasing informal work in Russia in the 2000s (e.g, Slonimczyk 2012). As regards the latter, synchronized changes in the minimum wage across the regions in 2001-2006 may imply insufficient variation in the data when the regression models include time effects.

\section{Summary and conclusion}

The minimum wage is a controversial issue in labor economics, economic policy, and politics. Its effects on overall employment as well as employment among low-skilled workers remain ambiguous, both theoretically and empirically. In this paper we extend the international literature on the minimum wage, in particular, the part that makes use of state-level panel data, using new data from Russia. Similarly to many other studies focusing on transition and posttransition countries (e.g., Muravyev 2008, Gorodnichenko et al. 2009, Eicher and Schreiber 2010), we take advantage of a unique institutional setting and frequent regulatory changes in Russia to address an important question of general interest for labor economists.

The Russian case is particularly interesting due to the unusually high magnitudes of minimum wage increases, approaching 100 percent in several cases. The dataset at our disposal, collected from various official sources, contains quarterly observations of minimum wages and labor market outcomes in 89 regions of Russia over 10 years, 2001 to 2010.

Based on fixed-effects regressions, we find considerable evidence of adverse effects of the minimum wage on the labor market. In particular, minimum wage hikes are associated with increased youth unemployment and increased informality. In contrast, there is no evidence of the disemployment effect of the minimum wage for workers aged 25-72. These findings are consistent with many previous studies, for both developed and developing economies, such as (Neumark and Wascher 2008; Nataraj et al. 2013).

We also find that the adjustment of the Russian labor market to minimum wage increases seems to occur fairly quickly, within a quarter following the increases. There is no evidence of advance reaction of employers to minimum wage hikes. 
Overall, our analysis supports the viewpoint that the minimum wage is a problematic policy instrument to tackle poverty and inequality. Instead of promoting greater income equality and reducing poverty, it seems to increase unemployment among the youth and force workers to take informal jobs, which are typically associated with lower job security, lower earnings, and a lack of social security protection. 


\section{References}

Addison, John T., Demet Ozturk, Orgul (2012) Minimum wages, labor market institutions, and female employment: A cross-country analysis. Industrial and Labor Relations Review, 65(4): 779-809.

Amin, Mohammad (2009) Labor Regulation and Employment in India's Retail Stores. Journal of Comparative Economics, 37(1): 47-61.

Ashenfelter, Orley, Farber, Henry, and Ransom, Michael R. (2010) Modern Models of Monopsony in Labor Markets: A Brief Survey. IZA Discussion Paper No. 4915, Institute for the Study of Labor.

Bazen, Stephen and Le Gallo, Julie (2009) The State-Federal Dichotomy in the Effects of Minimum Wages on Teenage Employment in the United States. Economics Letters, 105(3): 267-269.

Bhorat, Haroon, Ravi Kanbur, and Natasha Mayet (2012) Estimating the Causal Effect of Enforcement on Minimum Wage Compliance: The Case of South Africa. Review of Development Economics, 16(4): 608-623.

Boal, William M. and Michael R. Ransom (1997) Monopsony in the Labor Market. Journal of Economic Literature, 35(1): 86-112.

Boeri, Tito, Pietro Garibaldi, and Marta Ribeiro (2011) The Lighthouse Effect and Beyond. Review of Income and Wealth, 57(5): S54-S78.

Bosch M., and W. Maloney (2010) Comparative Analysis of Labor Market Dynamics Using Markov Processes: An Application to Informality. Labour Economics, 17(4): 621-631.

Brainerd, Elizabeth (1998) Winners and Losers in Russia's Economic Transition. The American Economic Review 88(5): 1094-1116.

Brown, Charles, Curtis Gilroy, and Andrew Kohen (1982) The Effect of the Minimum Wage on Employment and Unemployment. Journal of Economic Literature, 20(2): 487-528.

Cahuc, Pierre and Guy Laroque (2009) Optimal Taxation and Monopsonistic Labor Market: Does Monopsony justify the Minimum Wage? Working Paper hal-00396252, Ecole Polytechnique.

Card, David, and Alan B. Krueger (1994) Minimum Wages and Employment: A Case Study of the Fast Food Industry in New Jersey and Pennsylvania. American Economic Review 84(5): 772-93.

Carneiro, Francisco (2004) Are Minimum Wages to Blame for Informality in the Labour Market? Empirica, 31(4): 295-306.

Comola, Margherita and Luiz De Mello (2011) How Does Decentralized Minimum Wage Setting Affect Employment And Informality? The Case of Indonesia. Review of Income and Wealth, 57(s1): S79-S99.

Danziger, Leif (2010) Endogenous Monopsony and the Perverse Effect of the Minimum Wage in Small Firms. Labour Economics, 17(1): 224-229.

Dolton, Peter, Chiara Rosazza Bondibene, and Jonathan Wadsworth (2012) Employment, Inequality and the UK National Minimum Wage over the Medium-Term. Oxford Bulletin of Economics and Statistics, 74(1): 78-106. 
Dube, Arindrajit, T. William Lester, and Michael Reich (2010) Minimum Wage Effects Across State Borders: Estimates Using Contiguous Counties. Review of Economics and Statistics, 92(4): 945-964.

Eicher, Theo S. and Schreiber, Till (2010) Structural policies and growth: Time series evidence from a natural experiment. Journal of Development Economics, 91(1): 169-179.

Guriev, Sergey and Elena Vakulenko (2012) Convergence among Russian Regions. Paper presented as the IZA/Higher School of Economics Workshop: Labor Market Adjustment in the Commonwealth of Independent States, Central Asia and China in the Wake of the Great Recession, Moscow, October 5-6, 2012.

Gorodnichenko Yuriy, Jorge Martinez-Vazquez, Sabirianova Peter Klara (2009) Myth and Reality of Flat Tax Reform: Micro Estimates of Tax Evasion Response and Welfare Effects in Russia. Journal of Political Economy 117(3): 504-554.

Kertesi, Gabor, and Janos Kollo (2003) Fighting "Low Equilibria" by Doubling the Minimum Wage? Hungary's Experiment. IZA DP No. 970, Institute for the Study of Labor.

Khamis, Melanie (2013) Does the Minimum Wage Have a Higher Impact on the Informal than on the Formal Labor Market? Evidence from Quasi-Experiments. Applied Economics, 45(5): 477-495.

Kobzar, Elena (2009) Minimum Wage in Russia: Regional Labor Markets (Minimal'naya zarabotnaya plata v Rossii: regional'nye rynki truda). Working Paper, Laboratory for Labor Market Studies, Higher School of Economics, Moscow (in Russian).

Lee, David and Saez, Emmanuel (2012) Optimal Minimum Wage Policy in Competitive Labor Markets. Journal of Public Economics, 96(9-10): 739-749.

Lehmann, Hartmut, Tiziano Razzolini and Anzelika Zaiceva (2012) Job Separations and Informality in the Russian Labor Market. Resesarch in Labor Economics, 34: 257-290.

Lemos, Sara (2009) Minimum Wage Effects in a Developing Country. Labour Economics, 16(2): 224-237.

Lukiyanova, Anna (2011) Effects of Minimum Wages on the Russian Wage Distribution. Working Paper No 12, Series: Economics, Higher School of Economics, Moscow.

Magruder, Jeremy R. (2013) Can Minimum Wages Cause a Big Push? Evidence from Indonesia. Journal of Development Economics, 100(1): 48-62.

Manning, Alan (2011) Imperfect Competition in the Labor Market. In: O. Ashenfelter and D. Card (eds.), Handbook of Labor Economics, Elsevier, edition 1, volume 4b: 973-1041.

Muravyev, Alexander (2008) Human Capital Externalities: Evidence from the Transition Economy of Russia, Economics of Transition 16(3): 415-443.

Nataraj Shanthi, Francisco Perez-Arce, Krishna B. Kumar, Sinduja V. Srinivasan (2013) The impact of labor market regulation on employment in low-income countries: A meta-analysis. Journal of Economic Surveys, article in press, doi: 10.1111/joes.12040.

Neumark, David, and William Wascher (1992) Employment Effects of Minimum Wages and Subminimum Wages: Panel Data on State Minimum Wage Laws. Industrial and Labor Relations Review 46(1): 55-81.

Neumark, David and William L. Wascher (2008) Minimum Wages. Cambridge, Massachusetts: The MIT Press. 
Neumark, David, J.M. Ian Salas, and William Wascher (2013) Revisiting the Minimum Wage-Employment Debate: Throwing Out the Baby with the Bathwater? IZA DP No. 7166, Institute for the Study of Labor.

OECD (2013) OECD Indicators of Employment Protection. http://www.oecd.org/employment/emp/oecdindicatorsofemploymentprotection.htm.

Rama, Martin (2001) The Consequences of Doubling the Minimum Wage: The Case of Indonesia. Industrial and Labor Relations Review, 54(4): 864-881.

Rosstat (various years) Socio-economic situation in Russia. Moscow: Rosstat.

Schneider, Fridrich, A. Buehn and and C. Montenegro (2010) Shadow Economies All over the World. New Estimates for 162 countries from 1999 to 2007. World Bank Policy Research Working Paper No. 5356.

Sen, Anindya, Rybczynski, Kathleen, and Van De Waal, Corey (2011) Teen Employment, Poverty, and the Minimum Wage: Evidence from Canada. Labour Economics, 18(1): 36-47.

Slonimczyk, Fabian (2012) The Effect of Taxation on Informal Employment: Evidence from the Russian Flat Tax Reform. Research in Labor Economics, 34: 55-99.

Stigler, George J. (1946) The Economics of Minimum Wage Legislation. American Economic Review, 36(3): 358-365.

Strobl, Eric and Walsh, Frank (2011) The Ambiguous Effect of Minimum Wages on Hours. Labour Economics, 18(2): 218-228.

Williams, Colin C. and Windebank, Jan (2012) Informal Employment in Advanced Economies: Implications for Work and Welfare. London: Routledge.

Zavodny, Madeline (2000) The Effect of the Minimum Wage on Employment and Hours. Labour Economics, 7(6): 729-750. 
Chart 1. Dynamics of the Kaitz index, in \% (based on the federal minimum wage), 19852010.

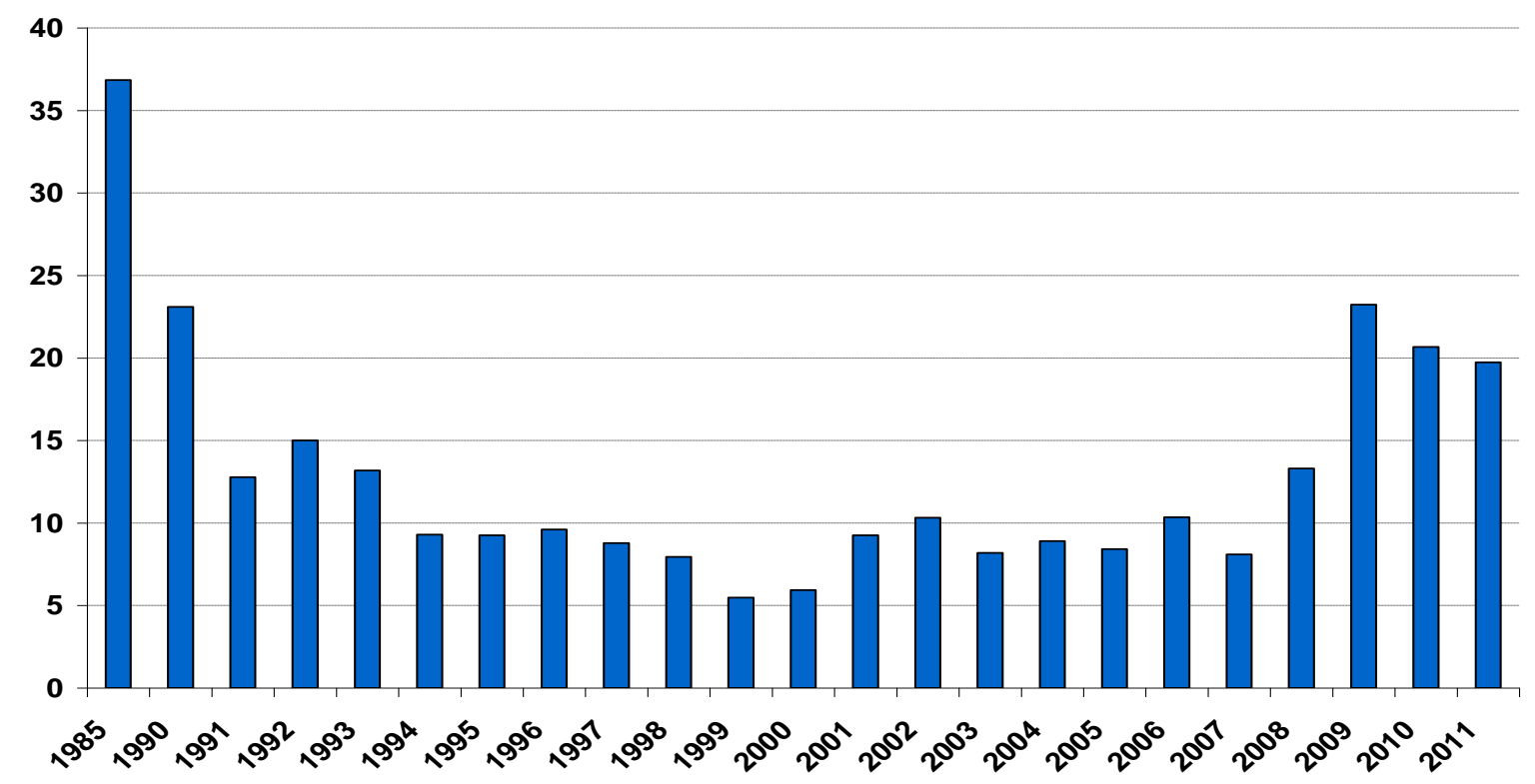


Chart 2. Percent of regions with own MW (above the federal level).

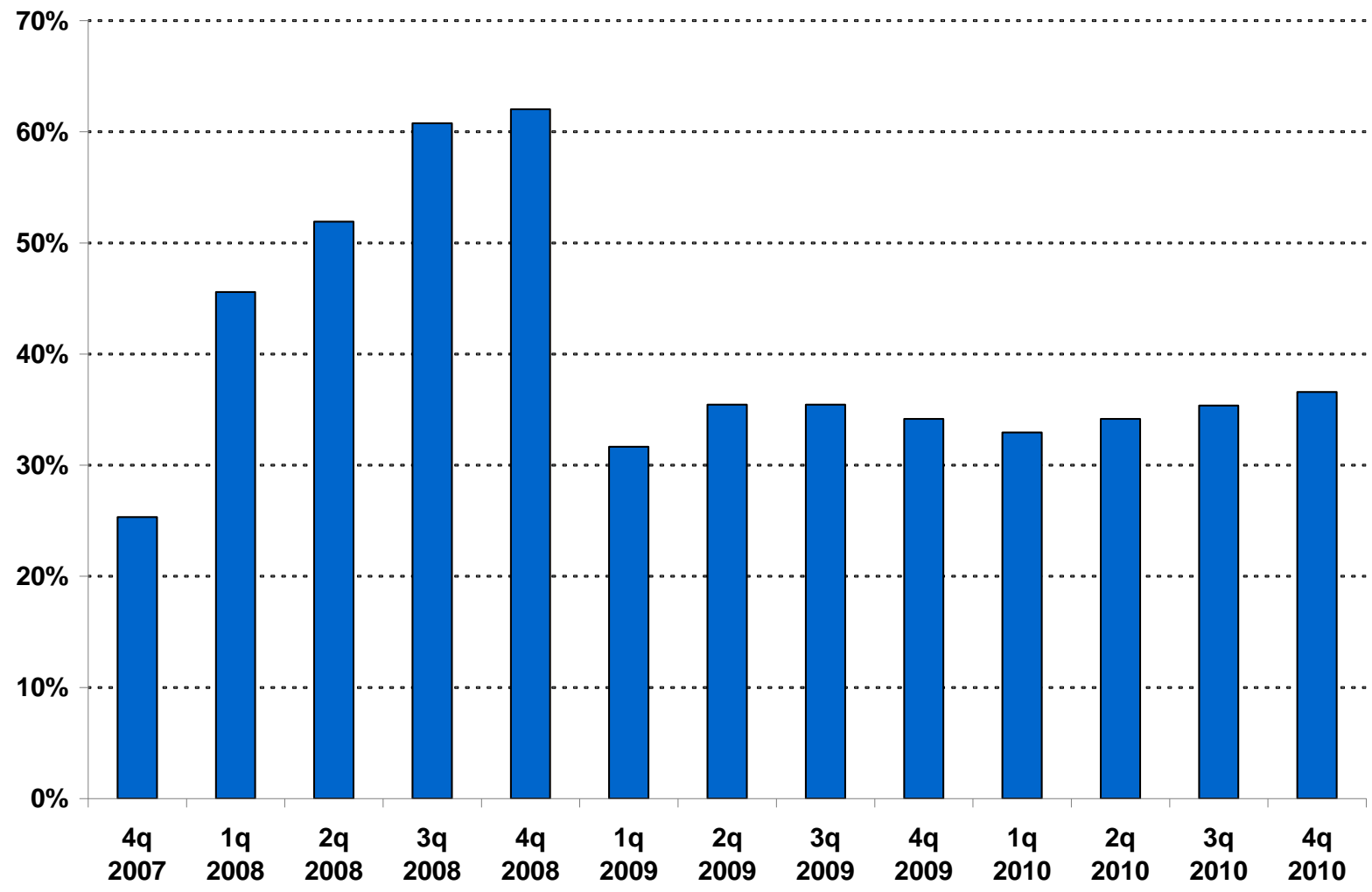


Chart 3. Monthly dynamics of the Kaitz index, in \% of the average wage, 2001-2010.

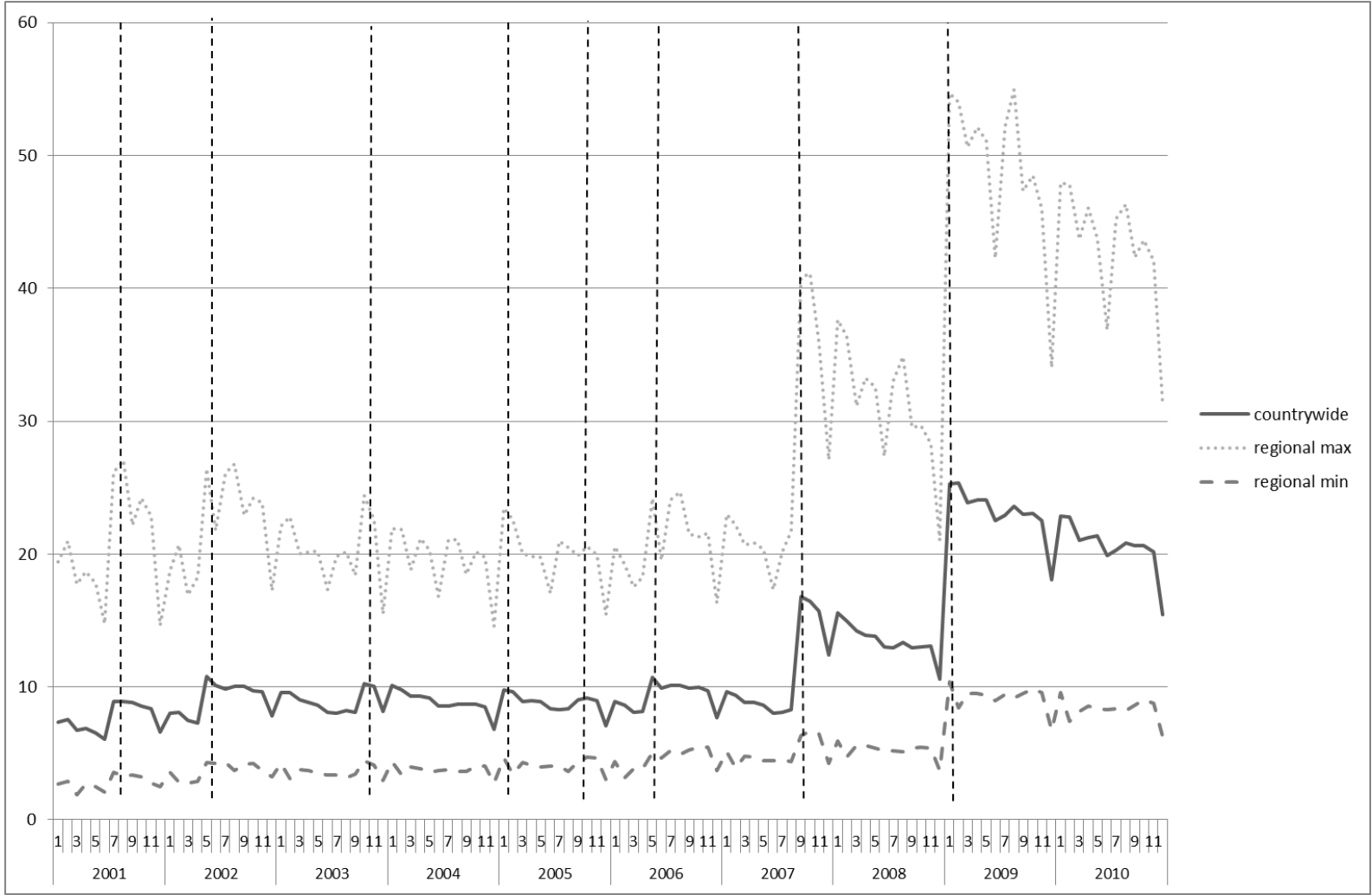

Note: moments of the federal minimum wage rises marked by vertical lines. 
Table 1. Federal minimum wage increases in Russia, 2001-2009.

\begin{tabular}{lcccccccc}
\hline \hline & 1 Jul & 1 May & 1 Oct & 1 Jan & 1 Sep & 1 May & 1 Sep & 1 Jan \\
& 2001 & 2002 & 2003 & 2005 & 2005 & 2006 & 2007 & 2009 \\
\hline Min wage hikes & & & & & & & & \\
From, Rubles & 200 & 300 & 450 & 600 & 720 & 800 & 1100 & 2300 \\
To, Rubles & 300 & 450 & 600 & 720 & 800 & 1100 & 2300 & 4330 \\
\% increase & 50 & 50 & 33 & 20 & 11 & 38 & 109 & 88 \\
Kaitz index & & & & & & & & \\
National & 0.09 & 0.11 & 0.1 & 0.1 & 0.09 & 0.11 & 0.17 & 0.25 \\
Max. regional & 0.26 & 0.26 & 0.24 & 0.23 & 0.20 & 0.24 & 0.46 & 0.55 \\
Min. regional & 0.04 & 0.04 & 0.04 & 0.05 & 0.04 & 0.05 & 0.08 & 0.14 \\
\hline \hline
\end{tabular}


Table 2. Descriptive statistics of the data.

Panel A. Full sample, 2001-2010.

\begin{tabular}{lccccc}
\hline \hline variable & mean & sd & $\min$ & p50 & $\max$ \\
\hline KAITZ & 18.09 & 9.97 & 3.20 & 14.54 & 54.93 \\
UNEMPL_15_72 & 8.99 & 5.94 & 0.91 & 7.82 & 54.29 \\
UNEMPL_25_72 & 7.60 & 5.34 & 0.52 & 6.53 & 51.59 \\
UNEMPL_15_24 & 17.24 & 8.26 & 3.63 & 15.75 & 51.93 \\
UNEMPL_FEM & 6.70 & 3.72 & 0.97 & 5.96 & 23.70 \\
INFORMAL_A & 16.78 & 7.87 & 1.22 & 15.62 & 47.44 \\
INFORMAL_B & 19.81 & 8.87 & 1.76 & 18.76 & 50.37 \\
SUBS_MIN & 0.06 & 0.24 & 0.00 & 0.00 & 1.00 \\
COVERAGE & 0.06 & 0.24 & 0.00 & 0.00 & 1.00 \\
DATA_DISCR & 0.03 & 0.17 & 0.00 & 0.00 & 1.00 \\
OUTPUT_CH & 105.31 & 21.26 & 53.00 & 104.90 & 560.00 \\
\hline \hline
\end{tabular}

Max. number of observations is 3160 .

Panel B. Sub- sample, 2001-2006.

\begin{tabular}{lccccc}
\hline \hline variable & mean & sd & min & p50 & max \\
\hline KAITZ & 12.59 & 3.70 & 3.20 & 12.18 & 31.08 \\
UNEMPL_15_72 & 9.40 & 6.11 & 0.91 & 8.16 & 54.29 \\
UNEMPL_25_72 & 8.01 & 5.59 & 0.77 & 6.80 & 51.59 \\
UNEMPL_15_24 & 17.71 & 8.67 & 4.33 & 16.03 & 51.93 \\
UNEMPL_FEM & 7.13 & 4.05 & 1.48 & 6.34 & 23.70 \\
INFORMAL_A & 15.75 & 7.56 & 1.22 & 14.44 & 47.44 \\
INFORMAL_B & 19.07 & 8.69 & 1.76 & 17.94 & 50.16 \\
SUBS_MIN & 0.00 & 0.00 & 0.00 & 0.00 & 0.00 \\
COVERAGE & 0.00 & 0.00 & 0.00 & 0.00 & 0.00 \\
DATA_DISCR & 0.00 & 0.00 & 0.00 & 0.00 & 0.00 \\
OUTPUT_CH & 108.01 & 17.66 & 53.00 & 105.40 & 260.00 \\
\hline \hline
\end{tabular}

Max. number of observations is 1896.

Panel B. Sub- sample, 2007-2010.

\begin{tabular}{lccccc}
\hline \hline variable & mean & sd & min & p50 & max \\
\hline KAITZ & 26.01 & 10.79 & 5.12 & 26.20 & 54.93 \\
UNEMPL_15_72 & 8.38 & 5.61 & 1.03 & 7.46 & 50.11 \\
UNEMPL_25_72 & 6.98 & 4.87 & 0.52 & 6.14 & 42.41 \\
UNEMPL_15_24 & 16.55 & 7.56 & 3.63 & 15.42 & 42.30 \\
UNEMPL_FEM & 6.06 & 3.06 & 0.97 & 5.52 & 16.77 \\
INFORMAL_A & 18.31 & 8.07 & 1.88 & 17.44 & 47.29 \\
INFORMAL_B & 20.93 & 9.03 & 2.42 & 20.01 & 50.37 \\
SUBS_MIN & 0.15 & 0.35 & 0.00 & 0.00 & 1.00 \\
COVERAGE & 0.15 & 0.36 & 0.00 & 0.00 & 1.00 \\
DATA_DISCR & 0.08 & 0.27 & 0.00 & 0.00 & 1.00 \\
OUTPUT_CH & 104.12 & 22.56 & 53.50 & 104.45 & 560.00 \\
\hline \hline
\end{tabular}

Max. number of observations is 1264. 
Table 3. Choosing the lag and lead structure for the full sample, 2001-2010.

Panel A. Choosing the number of lags.

\begin{tabular}{|c|c|c|c|c|c|c|}
\hline & 1 & 2 & 3 & 4 & 5 & 6 \\
\hline & $\begin{array}{c}\text { UNEMPL } \\
15-72 \\
\end{array}$ & $\begin{array}{c}\text { UNEMPL } \\
25-72 \\
\end{array}$ & $\begin{array}{c}\text { UNEMPL } \\
15-24 \\
\end{array}$ & $\begin{array}{l}\text { UNEMPL } \\
\text { FEMALE }\end{array}$ & $\begin{array}{c}\text { INFORML } \\
\text { A } \\
\end{array}$ & $\begin{array}{c}\text { INFORML } \\
\text { B } \\
\end{array}$ \\
\hline \multicolumn{7}{|c|}{ NO LAGS } \\
\hline \multirow[t]{2}{*}{ KAITZ } & -0.015 & -0.007 & -0.025 & -0.009 & 0.022 & 0.015 \\
\hline & $(0.029)$ & $(0.025)$ & $(0.053)$ & $(0.024)$ & $(0.044)$ & $(0.050)$ \\
\hline $\mathrm{R} 2$ & 0.14 & 0.14 & 0.08 & 0.13 & 0.17 & 0.13 \\
\hline \multicolumn{7}{|c|}{ ONE LAG } \\
\hline \multirow[t]{2}{*}{ KAITZ } & -0.028 & -0.015 & -0.078 & -0.011 & -0.010 & -0.017 \\
\hline & $(0.028)$ & $(0.023)$ & $(0.050)$ & $(0.022)$ & $(0.036)$ & $(0.042)$ \\
\hline \multirow[t]{2}{*}{ KAITZ_lag1 } & $0.031 *$ & 0.018 & $0.120 * * *$ & 0.004 & $0.074 * *$ & 0.072 \\
\hline & $(0.018)$ & $(0.014)$ & $(0.041)$ & $(0.014)$ & $(0.036)$ & $(0.044)$ \\
\hline $\mathrm{R} 2$ & 0.15 & 0.14 & 0.09 & 0.13 & 0.17 & 0.13 \\
\hline \multicolumn{7}{|c|}{ TWO LAGS } \\
\hline \multirow[t]{2}{*}{ KAITZ } & -0.027 & -0.015 & -0.074 & -0.010 & -0.011 & -0.019 \\
\hline & $(0.028)$ & $(0.023)$ & $(0.050)$ & $(0.022)$ & $(0.037)$ & $(0.043)$ \\
\hline \multirow[t]{2}{*}{ KAITZ_lag1 } & 0.015 & 0.011 & $0.078 * *$ & -0.004 & $0.086 * * *$ & $0.093 * *$ \\
\hline & $(0.014)$ & $(0.014)$ & $(0.033)$ & $(0.013)$ & $(0.029)$ & $(0.038)$ \\
\hline \multirow[t]{2}{*}{ KAITZ_lag2 } & 0.025 & 0.012 & 0.064 & 0.011 & -0.018 & -0.032 \\
\hline & $(0.018)$ & $(0.017)$ & $(0.039)$ & $(0.014)$ & $(0.022)$ & $(0.025)$ \\
\hline $\mathrm{R} 2$ & 0.15 & 0.14 & 0.09 & 0.13 & 0.17 & 0.13 \\
\hline \multicolumn{7}{|c|}{ THREE LAGS } \\
\hline \multirow[t]{2}{*}{ KAITZ } & -0.026 & -0.014 & -0.073 & -0.010 & -0.012 & -0.019 \\
\hline & $(0.028)$ & $(0.023)$ & $(0.050)$ & $(0.022)$ & $(0.037)$ & $(0.043)$ \\
\hline \multirow[t]{2}{*}{ KAITZ_lag1 } & 0.013 & 0.009 & $0.075 * *$ & -0.005 & $0.087 * * *$ & $0.094 * *$ \\
\hline & $(0.014)$ & $(0.014)$ & $(0.033)$ & $(0.013)$ & $(0.030)$ & $(0.039)$ \\
\hline \multirow[t]{2}{*}{ KAITZ_lag2 } & 0.010 & -0.003 & 0.038 & 0.000 & -0.011 & -0.026 \\
\hline & $(0.015)$ & $(0.016)$ & $(0.036)$ & $(0.013)$ & $(0.022)$ & $(0.027)$ \\
\hline \multirow[t]{2}{*}{ KAITZ_lag3 } & 0.025 & $0.025^{*}$ & 0.044 & 0.018 & -0.013 & -0.010 \\
\hline & $(0.017)$ & $(0.014)$ & $(0.041)$ & $(0.014)$ & $(0.028)$ & $(0.033)$ \\
\hline $\mathrm{R} 2$ & 0.15 & 0.14 & 0.09 & 0.13 & 0.17 & 0.13 \\
\hline \multicolumn{7}{|c|}{ FOUR LAGS } \\
\hline \multirow[t]{2}{*}{ KAITZ } & -0.027 & -0.014 & -0.073 & -0.010 & -0.012 & -0.019 \\
\hline & $(0.028)$ & $(0.023)$ & $(0.050)$ & $(0.022)$ & $(0.037)$ & $(0.043)$ \\
\hline \multirow[t]{2}{*}{ KAITZ_lag1 } & 0.012 & 0.008 & $0.070 * *$ & -0.007 & $0.083 * * *$ & $0.091 * *$ \\
\hline & $(0.014)$ & $(0.015)$ & $(0.034)$ & $(0.014)$ & $(0.030)$ & $(0.039)$ \\
\hline \multirow[t]{2}{*}{ KAITZ_lag2 } & 0.010 & -0.003 & 0.039 & 0.001 & -0.009 & -0.025 \\
\hline & $(0.015)$ & $(0.016)$ & $(0.036)$ & $(0.013)$ & $(0.022)$ & $(0.027)$ \\
\hline \multirow[t]{2}{*}{ KAITZ_lag3 } & 0.017 & 0.018 & 0.018 & 0.007 & -0.033 & -0.026 \\
\hline & $(0.020)$ & $(0.016)$ & $(0.041)$ & $(0.015)$ & $(0.030)$ & $(0.034)$ \\
\hline \multirow[t]{2}{*}{ KAITZ_lag4 } & 0.018 & 0.015 & 0.052 & $0.022 *$ & 0.041 & 0.033 \\
\hline & $(0.017)$ & $(0.015)$ & $(0.032)$ & $(0.013)$ & $(0.026)$ & $(0.029)$ \\
\hline $\mathrm{R} 2$ & 0.15 & 0.14 & 0.09 & 0.13 & 0.17 & 0.13 \\
\hline \multicolumn{7}{|l|}{ Number of lags: } \\
\hline AIC & 3 & 0 & 2 & 0 & 1 & 1 \\
\hline $\mathrm{BIC}$ & 0 & 0 & 1 & 0 & 0 & 0 \\
\hline
\end{tabular}

Note: The number of observations is 2,686 in all regressions. The results are obtained using the fixed-effects estimator. The table only reports the key variables of interest. Control variables that are not shown include: a dummy for partial coverage of the regional minimum wage, a dummy for the regional minimum wage being linked to the regional subsistence minimum, a dummy for discrepancies among different data sources regarding the regional minimum wage, and time effects (set of dummies for years and quarters). Cluster-robust standard errors with clustering on regions are reported in parentheses. Asterisks $* * *, * *, *$ denote significance at the $1 \%, 5 \%$, and $10 \%$ levels, respectively. 
Panel B. Testing for the leading regressor.

\begin{tabular}{|c|c|c|c|c|c|c|}
\hline & 1 & 2 & 3 & 4 & 5 & 6 \\
\hline & UNEMPL & UNEMPL & UNEMPL & UNEMPL & INFORML & INFORML \\
\hline & $15-72$ & $25-72$ & $15-24$ & FEMALE & A & B \\
\hline \multicolumn{7}{|c|}{ ONE LAG AND ONE LEAD } \\
\hline \multirow[t]{2}{*}{ KAITZ_lead1 } & 0.006 & 0.012 & 0.012 & 0.010 & -0.014 & -0.013 \\
\hline & $(0.016)$ & $(0.014)$ & $(0.028)$ & $(0.012)$ & $(0.027)$ & $(0.032)$ \\
\hline \multirow[t]{2}{*}{ KAITZ } & -0.033 & -0.023 & $-0.086^{*}$ & -0.018 & -0.001 & -0.009 \\
\hline & $(0.024)$ & $(0.019)$ & $(0.045)$ & $(0.019)$ & $(0.035)$ & $(0.042)$ \\
\hline \multirow[t]{2}{*}{ KAITZ_lag1 } & $0.031 *$ & 0.019 & $0.120 * * *$ & 0.004 & $0.073 * *$ & 0.072 \\
\hline & $(0.018)$ & $(0.015)$ & $(0.041)$ & $(0.014)$ & $(0.036)$ & $(0.044)$ \\
\hline $\mathrm{R} 2$ & 0.15 & 0.14 & 0.09 & 0.13 & 0.17 & 0.13 \\
\hline \multicolumn{7}{|l|}{$\begin{array}{l}\text { LR test: lead vs no } \\
\text { lead model }\end{array}$} \\
\hline Chi 2 & 0.17 & 0.78 & 0.15 & 0.68 & 0.31 & 0.17 \\
\hline Prob & 0.680 & 0.379 & 0.703 & 0.409 & 0.579 & 0.679 \\
\hline \multicolumn{7}{|c|}{ ONE LAG AND ONE LEAD INTERACTED WITH A DUMMY FOR ADVANCE ANNOUNCEMENT } \\
\hline \multirow[t]{2}{*}{ KAITZ_lead $1 * A D V$} & 0.012 & 0.012 & 0.013 & 0.007 & 0.006 & 0.008 \\
\hline & $(0.008)$ & $(0.008)$ & $(0.014)$ & $(0.006)$ & $(0.013)$ & $(0.016)$ \\
\hline \multirow[t]{2}{*}{ KAITZ } & -0.023 & -0.009 & -0.071 & -0.007 & -0.007 & -0.013 \\
\hline & $(0.030)$ & $(0.025)$ & $(0.053)$ & $(0.023)$ & $(0.039)$ & $(0.045)$ \\
\hline \multirow[t]{2}{*}{ KAITZ_lag1 } & $0.032 *$ & 0.019 & $0.121 * * *$ & 0.004 & $0.074 * *$ & 0.072 \\
\hline & $(0.018)$ & $(0.014)$ & $(0.040)$ & $(0.014)$ & $(0.036)$ & $(0.044)$ \\
\hline $\mathrm{R} 2$ & 0.15 & 0.14 & 0.09 & 0.13 & 0.17 & 0.13 \\
\hline \multicolumn{7}{|l|}{$\begin{array}{l}\text { LR test: lead vs no } \\
\text { lead model }\end{array}$} \\
\hline Chi 2 & 2.19 & 2.90 & 0.60 & 1.24 & 0.21 & 0.22 \\
\hline Prob & 0.139 & 0.088 & 0.439 & 0.266 & 0.643 & 0.640 \\
\hline
\end{tabular}

Note: The number of observations is 2,686 in all regressions. The results are obtained using the fixed-effects estimator. The table only reports the key variables of interest. Control variables that are not shown include: a dummy for partial coverage of the regional minimum wage, a dummy for the regional minimum wage being linked to the regional subsistence minimum, a dummy for discrepancies among different data sources regarding the regional minimum wage, and time effects (set of dummies for years and quarters). Cluster-robust standard errors with clustering on regions are reported in parentheses. Asterisks $* * *, * *, *$ denote significance at the $1 \%, 5 \%$, and $10 \%$ levels, respectively. 
Table 4. Main results and robustness checks for the full sample, 2001-2010.

\begin{tabular}{|c|c|c|c|c|c|c|}
\hline & 1 & 2 & 3 & 4 & 5 & 6 \\
\hline & $\begin{array}{c}\text { UNEMPL } \\
15-72\end{array}$ & $\begin{array}{c}\text { UNEMPL } \\
25-72\end{array}$ & $\begin{array}{c}\text { UNEMPL } \\
15-24\end{array}$ & $\begin{array}{l}\text { UNEMPL } \\
\text { FEMALE }\end{array}$ & $\begin{array}{c}\text { INFORML } \\
\text { A }\end{array}$ & $\begin{array}{c}\text { INFORML } \\
\text { B }\end{array}$ \\
\hline \multicolumn{7}{|c|}{ BASELINE MODEL } \\
\hline \multirow[t]{2}{*}{ KAITZ } & -0.014 & -0.009 & -0.046 & -0.004 & -0.013 & -0.021 \\
\hline & $(0.026)$ & $(0.022)$ & $(0.045)$ & $(0.020)$ & $(0.037)$ & $(0.042)$ \\
\hline \multirow[t]{2}{*}{ KAITZ_lag1 } & $0.033^{*}$ & 0.021 & $0.105^{* * *}$ & 0.006 & $0.080 * *$ & $0.077^{*}$ \\
\hline & $(0.017)$ & $(0.015)$ & $(0.037)$ & $(0.015)$ & $(0.035)$ & $(0.043)$ \\
\hline R2 & 0.14 & 0.14 & 0.08 & 0.13 & 0.21 & 0.16 \\
\hline $\mathrm{N}$ & 3002 & 3002 & 3002 & 3002 & 3002 & 3002 \\
\hline \multicolumn{7}{|c|}{ NORTHERN TERRITORIES EXCLUDED } \\
\hline \multirow[t]{2}{*}{ KAITZ } & -0.020 & -0.007 & -0.047 & -0.018 & -0.045 & -0.043 \\
\hline & $(0.028)$ & $(0.024)$ & $(0.049)$ & $(0.022)$ & $(0.037)$ & $(0.043)$ \\
\hline \multirow[t]{2}{*}{ KAITZ_lag1 } & 0.025 & 0.012 & $0.097 * *$ & -0.007 & 0.063 & 0.073 \\
\hline & $(0.019)$ & $(0.017)$ & $(0.045)$ & $(0.016)$ & $(0.040)$ & $(0.052)$ \\
\hline R2 & 0.13 & 0.13 & 0.10 & 0.12 & 0.21 & 0.15 \\
\hline $\mathrm{N}$ & 2204 & 2204 & 2204 & 2204 & 2204 & 2204 \\
\hline \multicolumn{7}{|c|}{ REGIONS WITH STRONG LABOR MARKETS EXCLUDED } \\
\hline \multirow[t]{2}{*}{ KAITZ } & -0.015 & -0.010 & -0.042 & -0.005 & -0.018 & -0.026 \\
\hline & $(0.027)$ & $(0.023)$ & $(0.046)$ & $(0.021)$ & $(0.038)$ & $(0.043)$ \\
\hline \multirow[t]{2}{*}{ KAITZ_lag1 } & $0.034^{*}$ & 0.022 & $0.109 * * *$ & 0.006 & $0.078 * *$ & $0.076^{*}$ \\
\hline & $(0.018)$ & $(0.015)$ & $(0.038)$ & $(0.015)$ & $(0.036)$ & $(0.044)$ \\
\hline $\mathrm{R} 2$ & 0.14 & 0.14 & 0.08 & 0.13 & 0.22 & 0.16 \\
\hline $\mathrm{N}$ & 2926 & 2926 & 2926 & 2926 & 2926 & 2926 \\
\hline \multicolumn{7}{|c|}{ REGIONS WITH WEAK LABOR MARKETS EXCLUDED } \\
\hline \multirow[t]{2}{*}{ KAITZ } & 0.004 & 0.005 & -0.018 & 0.009 & -0.018 & -0.026 \\
\hline & $(0.024)$ & $(0.019)$ & $(0.045)$ & $(0.018)$ & $(0.037)$ & $(0.043)$ \\
\hline \multirow[t]{2}{*}{ KAITZ_lag1 } & 0.024 & 0.018 & $0.109 * * *$ & 0.010 & $0.083 * *$ & $0.076^{*}$ \\
\hline & $(0.016)$ & $(0.015)$ & $(0.039)$ & $(0.014)$ & $(0.036)$ & $(0.045)$ \\
\hline R2 & 0.16 & 0.16 & 0.08 & 0.13 & 0.21 & 0.15 \\
\hline $\mathrm{N}$ & 2888 & 2888 & 2888 & 2888 & 2888 & 2888 \\
\hline \multicolumn{7}{|c|}{ REGRESSIONS WITH WEIGHTS } \\
\hline \multirow[t]{2}{*}{ KAITZ } & -0.005 & -0.003 & -0.018 & -0.008 & 0.015 & 0.010 \\
\hline & $(0.029)$ & $(0.024)$ & $(0.044)$ & $(0.021)$ & $(0.040)$ & $(0.046)$ \\
\hline \multirow[t]{2}{*}{ KAITZ_lag1 } & 0.009 & 0.007 & $0.080 * *$ & 0.003 & $0.087 * *$ & $0.082 *$ \\
\hline & $(0.014)$ & $(0.014)$ & $(0.035)$ & $(0.014)$ & $(0.040)$ & $(0.047)$ \\
\hline R2 & 0.19 & 0.19 & 0.10 & 0.17 & 0.24 & 0.18 \\
\hline $\mathrm{N}$ & 3002 & 3002 & 3002 & 3002 & 3002 & 3002 \\
\hline
\end{tabular}

Note: The results are obtained using the fixed-effects estimator. The table only reports the key variables of interest. Control variables that are not shown include: a dummy for partial coverage of the regional minimum wage, a dummy for the regional minimum wage being linked to the regional subsistence minimum, a dummy for discrepancies among different data sources regarding the regional minimum wage, and time effects (set of dummies for years and quarters). Cluster-robust standard errors with clustering on regions are reported in parentheses. Asterisks $* * *, * *, *$ denote significance at the $1 \%, 5 \%$, and $10 \%$ levels, respectively. 
Table 5. Main results and robustness checks for the sub-sample 2001-2006.

\begin{tabular}{|c|c|c|c|c|c|c|}
\hline & 1 & 2 & 3 & 4 & 5 & 6 \\
\hline & $\begin{array}{c}\text { UNEMPL } \\
15-72\end{array}$ & $\begin{array}{c}\text { UNEMPL } \\
25-72\end{array}$ & $\begin{array}{c}\text { UNEMPL } \\
15-24\end{array}$ & $\begin{array}{l}\text { UNEMPL } \\
\text { FEMALE }\end{array}$ & $\begin{array}{c}\text { INFORML } \\
\text { A }\end{array}$ & $\begin{array}{c}\text { INFORML } \\
\text { B }\end{array}$ \\
\hline \multicolumn{7}{|c|}{ BASELINE MODEL } \\
\hline \multirow[t]{2}{*}{ KAITZ } & 0.065 & 0.020 & 0.157 & -0.027 & -0.011 & -0.014 \\
\hline & $(0.055)$ & $(0.058)$ & $(0.121)$ & $(0.039)$ & $(0.065)$ & $(0.078)$ \\
\hline \multirow[t]{2}{*}{ KAITZ_lag1 } & 0.072 & 0.083 & $0.197 *$ & -0.010 & -0.047 & -0.072 \\
\hline & $(0.054)$ & $(0.060)$ & $(0.101)$ & $(0.049)$ & $(0.069)$ & $(0.086)$ \\
\hline $\mathrm{R} 2$ & 0.08 & 0.08 & 0.03 & 0.08 & 0.24 & 0.18 \\
\hline $\mathrm{N}$ & 1738 & 1738 & 1738 & 1738 & 1738 & 1738 \\
\hline \multicolumn{7}{|c|}{ NORTHERN TERRITORIES EXCLUDED } \\
\hline \multirow[t]{2}{*}{ KAITZ } & $0.103 *$ & 0.062 & 0.187 & -0.017 & -0.032 & -0.030 \\
\hline & $(0.061)$ & $(0.069)$ & $(0.131)$ & $(0.040)$ & $(0.058)$ & $(0.080)$ \\
\hline \multirow[t]{2}{*}{ KAITZ_lag1 } & 0.039 & 0.052 & 0.160 & -0.036 & -0.045 & -0.073 \\
\hline & $(0.043)$ & $(0.060)$ & $(0.108)$ & $(0.051)$ & $(0.074)$ & $(0.095)$ \\
\hline $\mathrm{R} 2$ & 0.06 & 0.06 & 0.04 & 0.06 & 0.23 & 0.16 \\
\hline $\mathrm{N}$ & 1276 & 1276 & 1276 & 1276 & 1276 & 1276 \\
\hline \multicolumn{7}{|c|}{ REGIONS WITH STRONG LABOR MARKETS EXCLUDED } \\
\hline \multirow[t]{2}{*}{ KAITZ } & 0.069 & 0.023 & 0.168 & -0.026 & -0.015 & -0.021 \\
\hline & $(0.056)$ & $(0.058)$ & $(0.123)$ & $(0.040)$ & $(0.066)$ & $(0.080)$ \\
\hline \multirow[t]{2}{*}{ KAITZ_lag1 } & 0.076 & 0.087 & $0.200^{*}$ & -0.008 & -0.051 & -0.076 \\
\hline & $(0.055)$ & $(0.061)$ & $(0.102)$ & $(0.049)$ & $(0.070)$ & $(0.087)$ \\
\hline $\mathrm{R} 2$ & 0.08 & 0.08 & 0.04 & 0.08 & 0.25 & 0.18 \\
\hline $\mathrm{N}$ & 1694 & 1694 & 1694 & 1694 & 1694 & 1694 \\
\hline \multicolumn{7}{|c|}{ REGIONS WITH WEAK LABOR MARKETS EXCLUDED } \\
\hline \multirow[t]{2}{*}{ KAITZ } & 0.025 & -0.031 & $0.239 * *$ & -0.025 & 0.006 & 0.002 \\
\hline & $(0.046)$ & $(0.042)$ & $(0.112)$ & $(0.042)$ & $(0.065)$ & $(0.079)$ \\
\hline \multirow[t]{2}{*}{ KAITZ_lag1 } & 0.027 & 0.043 & 0.158 & -0.003 & -0.079 & -0.103 \\
\hline & $(0.040)$ & $(0.042)$ & $(0.107)$ & $(0.049)$ & $(0.073)$ & $(0.093)$ \\
\hline $\mathrm{R} 2$ & 0.10 & 0.11 & 0.04 & 0.08 & 0.24 & 0.17 \\
\hline $\mathrm{N}$ & 1672 & 1672 & 1672 & 1672 & 1672 & 1672 \\
\hline \multicolumn{7}{|c|}{ REGRESSIONS WITH WEIGHTS } \\
\hline \multirow[t]{2}{*}{ KAITZ } & 0.064 & 0.020 & 0.080 & -0.023 & 0.108 & 0.111 \\
\hline & $(0.056)$ & $(0.048)$ & $(0.155)$ & $(0.038)$ & $(0.074)$ & $(0.087)$ \\
\hline \multirow[t]{2}{*}{ KAITZ_lag1 } & 0.021 & 0.018 & 0.029 & 0.010 & -0.017 & -0.048 \\
\hline & $(0.040)$ & $(0.049)$ & $(0.093)$ & $(0.050)$ & $(0.071)$ & $(0.083)$ \\
\hline $\mathrm{R} 2$ & 0.12 & 0.12 & 0.04 & 0.12 & 0.26 & 0.19 \\
\hline $\mathrm{N}$ & 1738 & 1738 & 1738 & 1738 & 1738 & 1738 \\
\hline
\end{tabular}

Note: The results are obtained using the fixed-effects estimator. The table only reports the key variables of interest. Control variables that are not shown include: a dummy for partial coverage of the regional minimum wage, a dummy for the regional minimum wage being linked to the regional subsistence minimum, a dummy for discrepancies among different data sources regarding the regional minimum wage, and time effects (set of dummies for years and quarters). Cluster-robust standard errors with clustering on regions are reported in parentheses. Asterisks $* * *, * *, *$ denote significance at the $1 \%, 5 \%$, and $10 \%$ levels, respectively. 
Table 6. Main results and robustness checks for the sub-sample 2007-2010.

\begin{tabular}{|c|c|c|c|c|c|c|}
\hline & 1 & 2 & 3 & 4 & 5 & 6 \\
\hline & $\begin{array}{c}\text { UNEMPL } \\
15-72\end{array}$ & $\begin{array}{c}\text { UNEMPL } \\
25-72\end{array}$ & $\begin{array}{c}\text { UNEMPL } \\
15-24\end{array}$ & $\begin{array}{l}\text { UNEMPL } \\
\text { FEMALE }\end{array}$ & $\begin{array}{c}\text { INFORML } \\
\text { A }\end{array}$ & $\begin{array}{c}\text { INFORML } \\
\text { B }\end{array}$ \\
\hline \multicolumn{7}{|c|}{ BASELINE MODEL } \\
\hline \multirow[t]{2}{*}{ KAITZ } & -0.026 & -0.017 & -0.056 & -0.013 & -0.008 & -0.010 \\
\hline & $(0.028)$ & $(0.022)$ & $(0.042)$ & $(0.020)$ & $(0.035)$ & $(0.044)$ \\
\hline \multirow[t]{2}{*}{ KAITZ_lag1 } & $0.029 *$ & 0.013 & $0.121 * * *$ & 0.004 & $0.098 * * *$ & $0.099 * *$ \\
\hline & $(0.016)$ & $(0.015)$ & $(0.045)$ & $(0.013)$ & $(0.034)$ & $(0.043)$ \\
\hline $\mathrm{R} 2$ & 0.20 & 0.20 & 0.13 & 0.14 & 0.11 & 0.13 \\
\hline $\mathrm{N}$ & 1343 & 1343 & 1343 & 1343 & 1343 & 1343 \\
\hline \multicolumn{7}{|c|}{ NORTHERN TERRITORIES EXCLUDED } \\
\hline \multirow[t]{2}{*}{ KAITZ } & -0.034 & -0.015 & -0.072 & -0.016 & -0.021 & -0.017 \\
\hline & $(0.031)$ & $(0.023)$ & $(0.045)$ & $(0.022)$ & $(0.036)$ & $(0.046)$ \\
\hline \multirow[t]{2}{*}{ KAITZ_lag1 } & 0.025 & 0.008 & $0.100 *$ & -0.002 & $0.097 * *$ & $0.111 * *$ \\
\hline & $(0.019)$ & $(0.018)$ & $(0.051)$ & $(0.016)$ & $(0.037)$ & $(0.049)$ \\
\hline $\mathrm{R} 2$ & 0.20 & 0.21 & 0.15 & 0.13 & 0.09 & 0.11 \\
\hline $\mathrm{N}$ & 986 & 986 & 986 & 986 & 986 & 986 \\
\hline \multicolumn{7}{|c|}{ REGIONS WITH STRONG LABOR MARKETS EXCLUDED } \\
\hline \multirow[t]{2}{*}{ KAITZ } & -0.027 & -0.018 & -0.056 & -0.013 & -0.010 & -0.012 \\
\hline & $(0.029)$ & $(0.022)$ & $(0.043)$ & $(0.021)$ & $(0.036)$ & $(0.045)$ \\
\hline \multirow[t]{2}{*}{ KAITZ_lag1 } & $0.029 *$ & 0.014 & $0.122 * * *$ & 0.004 & $0.099 * * *$ & $0.100 * *$ \\
\hline & $(0.016)$ & $(0.015)$ & $(0.045)$ & $(0.014)$ & $(0.035)$ & $(0.044)$ \\
\hline R2 & 0.20 & 0.20 & 0.13 & 0.13 & 0.11 & 0.13 \\
\hline $\mathrm{N}$ & 1309 & 1309 & 1309 & 1309 & 1309 & 1309 \\
\hline \multicolumn{7}{|c|}{ REGIONS WITH WEAK LABOR MARKETS EXCLUDED } \\
\hline \multirow[t]{2}{*}{ KAITZ } & -0.013 & -0.006 & -0.050 & -0.006 & -0.020 & -0.021 \\
\hline & $(0.028)$ & $(0.020)$ & $(0.045)$ & $(0.021)$ & $(0.036)$ & $(0.046)$ \\
\hline \multirow[t]{2}{*}{ KAITZ_lag1 } & 0.020 & 0.010 & $0.120 * *$ & 0.002 & $0.103 * * *$ & $0.100 * *$ \\
\hline & $(0.016)$ & $(0.015)$ & $(0.047)$ & $(0.014)$ & $(0.035)$ & $(0.046)$ \\
\hline $\mathrm{R} 2$ & 0.23 & 0.24 & 0.14 & 0.14 & 0.12 & 0.13 \\
\hline $\mathrm{N}$ & 1292 & 1292 & 1292 & 1292 & 1292 & 1292 \\
\hline \multicolumn{7}{|c|}{ REGRESSIONS WITH WEIGHTS } \\
\hline \multirow[t]{2}{*}{ KAITZ } & -0.014 & -0.011 & -0.026 & -0.011 & 0.005 & -0.002 \\
\hline & $(0.022)$ & $(0.018)$ & $(0.035)$ & $(0.016)$ & $(0.031)$ & $(0.037)$ \\
\hline \multirow[t]{2}{*}{ KAITZ_lag1 } & 0.007 & 0.009 & $0.094 * *$ & 0.003 & $0.082 * *$ & $0.078 *$ \\
\hline & $(0.014)$ & $(0.014)$ & $(0.040)$ & $(0.012)$ & $(0.034)$ & $(0.040)$ \\
\hline $\mathrm{R} 2$ & 0.27 & 0.28 & 0.16 & 0.20 & 0.14 & 0.17 \\
\hline $\mathrm{N}$ & 1343 & 1343 & 1343 & 1343 & 1343 & 1343 \\
\hline \multicolumn{7}{|c|}{ REGRESSIONS WITH OUTPUT CHANGE } \\
\hline \multirow[t]{2}{*}{ KAITZ } & -0.027 & -0.019 & -0.062 & -0.015 & -0.006 & -0.008 \\
\hline & $(0.028)$ & $(0.021)$ & $(0.041)$ & $(0.020)$ & $(0.035)$ & $(0.044)$ \\
\hline \multirow[t]{2}{*}{ KAITZ_lag1 } & $0.028 *$ & 0.012 & $0.116^{* *}$ & 0.003 & $0.100 * * *$ & $0.101 * *$ \\
\hline & $(0.016)$ & $(0.014)$ & $(0.045)$ & $(0.013)$ & $(0.034)$ & $(0.043)$ \\
\hline \multirow[t]{2}{*}{ OUTPUT_CH } & -0.003 & -0.005 & $-0.019 * *$ & -0.006 & 0.008 & 0.007 \\
\hline & $(0.004)$ & $(0.005)$ & $(0.008)$ & $(0.005)$ & $(0.009)$ & $(0.010)$ \\
\hline $\mathrm{R} 2$ & 0.20 & 0.20 & 0.13 & 0.14 & 0.11 & 0.13 \\
\hline $\mathrm{N}$ & 1343 & 1343 & 1343 & 1343 & 1343 & 1343 \\
\hline
\end{tabular}

Note: The results are obtained using the fixed-effects estimator. The table only reports the key variables of interest. Control variables that are not shown include: a dummy for partial coverage of the regional minimum wage, a dummy for the regional minimum wage being linked to the regional subsistence minimum, a dummy for discrepancies among different data sources regarding the regional minimum wage, and time effects (set of dummies for years and quarters). Cluster-robust standard errors with clustering on regions are reported in parentheses. Asterisks ***,**, * denote significance at the $1 \%, 5 \%$, and $10 \%$ levels, respectively. 
Appendix. Table A1. Choosing the lag and lead structure for the sub-sample, 2001-2006.

Panle A. Lags.

\begin{tabular}{|c|c|c|c|c|c|c|}
\hline & 1 & 2 & 3 & 4 & 5 & 6 \\
\hline & UNEMPL & UNEMPL & UNEMPL & UNEMPL & INFORML & INFORML \\
\hline & $15-72$ & $25-72$ & $15-24$ & FEMALE & A & B \\
\hline \multicolumn{7}{|c|}{ NO LAGS } \\
\hline \multirow[t]{2}{*}{ KAITZ } & -0.050 & -0.042 & -0.018 & $-0.086^{*}$ & 0.018 & 0.038 \\
\hline & $(0.055)$ & $(0.068)$ & $(0.154)$ & $(0.045)$ & $(0.077)$ & $(0.092)$ \\
\hline $\mathrm{R} 2$ & 0.09 & 0.09 & 0.04 & 0.09 & 0.19 & 0.14 \\
\hline \multicolumn{7}{|c|}{ ONE LAG } \\
\hline \multirow[t]{2}{*}{ KAITZ } & -0.053 & -0.047 & -0.027 & $-0.085 *$ & 0.023 & 0.045 \\
\hline & $(0.054)$ & $(0.065)$ & $(0.153)$ & $(0.044)$ & $(0.076)$ & $(0.093)$ \\
\hline \multirow[t]{2}{*}{ KAITZ_lag1 } & 0.049 & 0.091 & 0.148 & -0.023 & -0.095 & -0.108 \\
\hline & $(0.062)$ & $(0.079)$ & $(0.127)$ & $(0.051)$ & $(0.089)$ & $(0.105)$ \\
\hline $\mathrm{R} 2$ & 0.09 & 0.09 & 0.04 & 0.09 & 0.19 & 0.14 \\
\hline \multicolumn{7}{|c|}{ TWO LAGS } \\
\hline \multirow[t]{2}{*}{ KAITZ } & -0.032 & -0.036 & -0.011 & $-0.087 *$ & 0.005 & 0.018 \\
\hline & $(0.057)$ & $(0.073)$ & $(0.154)$ & $(0.047)$ & $(0.082)$ & $(0.095)$ \\
\hline \multirow[t]{2}{*}{ KAITZ_lag1 } & 0.020 & 0.074 & 0.125 & -0.020 & -0.068 & -0.069 \\
\hline & $(0.061)$ & $(0.069)$ & $(0.115)$ & $(0.051)$ & $(0.082)$ & $(0.099)$ \\
\hline \multirow[t]{2}{*}{ KAITZ_lag2 } & $0.119 *$ & 0.068 & 0.092 & -0.012 & -0.107 & -0.154 \\
\hline & $(0.065)$ & $(0.077)$ & $(0.119)$ & $(0.047)$ & $(0.083)$ & $(0.097)$ \\
\hline $\mathrm{R} 2$ & 0.09 & 0.09 & 0.04 & 0.09 & 0.19 & 0.14 \\
\hline \multicolumn{7}{|c|}{ THREE LAGS } \\
\hline \multirow[t]{2}{*}{ KAITZ } & -0.028 & -0.035 & 0.007 & $-0.084 *$ & 0.016 & 0.031 \\
\hline & $(0.057)$ & $(0.068)$ & $(0.148)$ & $(0.049)$ & $(0.081)$ & $(0.096)$ \\
\hline \multirow[t]{2}{*}{ KAITZ_lag1 } & 0.016 & 0.073 & 0.109 & -0.023 & -0.078 & -0.080 \\
\hline & $(0.064)$ & $(0.074)$ & $(0.117)$ & $(0.052)$ & $(0.084)$ & $(0.100)$ \\
\hline \multirow[t]{2}{*}{ KAITZ_lag2 } & $0.124^{*}$ & 0.069 & 0.116 & -0.008 & -0.093 & -0.138 \\
\hline & $(0.066)$ & $(0.070)$ & $(0.116)$ & $(0.050)$ & $(0.084)$ & $(0.098)$ \\
\hline \multirow[t]{2}{*}{ KAITZ_lag3 } & -0.053 & -0.012 & -0.227 & -0.040 & -0.140 & -0.157 \\
\hline & $(0.109)$ & $(0.124)$ & $(0.194)$ & $(0.080)$ & $(0.125)$ & $(0.140)$ \\
\hline $\mathrm{R} 2$ & 0.09 & 0.09 & 0.04 & 0.09 & 0.19 & 0.14 \\
\hline \multicolumn{7}{|c|}{ FOUR LAGS } \\
\hline \multirow[t]{2}{*}{ KAITZ } & -0.022 & -0.024 & 0.034 & -0.084 & 0.002 & 0.018 \\
\hline & $(0.072)$ & $(0.087)$ & $(0.156)$ & $(0.053)$ & $(0.089)$ & $(0.099)$ \\
\hline \multirow[t]{2}{*}{ KAITZ_lag1 } & 0.010 & 0.063 & 0.082 & -0.023 & -0.064 & -0.068 \\
\hline & $(0.072)$ & $(0.074)$ & $(0.121)$ & $(0.060)$ & $(0.080)$ & $(0.097)$ \\
\hline \multirow[t]{2}{*}{ KAITZ_lag2 } & $0.128^{*}$ & 0.077 & 0.135 & -0.008 & -0.102 & -0.147 \\
\hline & $(0.075)$ & $(0.082)$ & $(0.114)$ & $(0.052)$ & $(0.090)$ & $(0.104)$ \\
\hline \multirow[t]{2}{*}{ KAITZ_lag3 } & -0.050 & -0.007 & -0.214 & -0.040 & -0.146 & -0.163 \\
\hline & $(0.113)$ & $(0.132)$ & $(0.201)$ & $(0.080)$ & $(0.131)$ & $(0.145)$ \\
\hline \multirow[t]{2}{*}{ KAITZ_lag4 } & 0.029 & 0.051 & 0.133 & -0.001 & -0.067 & -0.061 \\
\hline & (0.119) & $(0.127)$ & $(0.134)$ & $(0.065)$ & $(0.089)$ & $(0.100)$ \\
\hline $\mathrm{R} 2$ & 0.09 & 0.09 & 0.04 & 0.09 & 0.19 & 0.14 \\
\hline \multicolumn{7}{|l|}{ Lags: } \\
\hline AIC & 2 & 1 & 0 & 0 & 0 & 0 \\
\hline $\mathrm{BIC}$ & 0 & 0 & 0 & 0 & 0 & 0 \\
\hline
\end{tabular}

Note: The number of observations is fixed at 1580 in all regressions. The results are obtained using the fixedeffects estimator. The table only reports the key variables of interest. Control variables that are not shown include: a dummy for partial coverage of the regional minimum wage, a dummy for the regional minimum wage being linked to the regional subsistence minimum, a dummy for discrepancies among different data sources regarding the regional minimum wage, and time effects (set of dummies for years and quarters). Cluster-robust standard errors with clustering on regions are reported in parentheses. Asterisks ***, **, * denote significance at the $1 \%, 5 \%$, and $10 \%$ levels, respectively. 
Panel B. Leads.

\begin{tabular}{|c|c|c|c|c|c|c|}
\hline & 1 & 2 & 3 & 4 & 5 & 6 \\
\hline & $\begin{array}{c}\text { UNEMPL } \\
15-72\end{array}$ & $\begin{array}{l}\text { UNEMPL } \\
25-72\end{array}$ & $\begin{array}{c}\text { UNEMPL } \\
15-24\end{array}$ & $\begin{array}{l}\text { UNEMPL } \\
\text { FEMALE }\end{array}$ & $\begin{array}{c}\text { INFORML } \\
\text { A }\end{array}$ & $\begin{array}{l}\text { INFORML } \\
\text { B }\end{array}$ \\
\hline \multicolumn{7}{|c|}{ ONE LAG AND ONE LEAD } \\
\hline \multirow[t]{2}{*}{ KAITZ_lead1 } & 0.106 & 0.093 & 0.113 & 0.033 & 0.006 & -0.025 \\
\hline & $(0.116)$ & $(0.121)$ & $(0.145)$ & $(0.085)$ & $(0.140)$ & $(0.174)$ \\
\hline \multirow[t]{2}{*}{ KAITZ } & -0.061 & -0.054 & -0.036 & $-0.087 *$ & 0.023 & 0.047 \\
\hline & $(0.050)$ & $(0.058)$ & $(0.147)$ & $(0.045)$ & $(0.076)$ & $(0.091)$ \\
\hline \multirow[t]{2}{*}{ KAITZ_lag1 } & 0.077 & 0.115 & 0.177 & -0.015 & -0.093 & -0.114 \\
\hline & $(0.081)$ & $(0.101)$ & $(0.130)$ & $(0.053)$ & $(0.101)$ & $(0.117)$ \\
\hline R2 & 0.09 & 0.09 & 0.04 & 0.09 & 0.19 & 0.14 \\
\hline \multicolumn{7}{|l|}{$\begin{array}{l}\text { LR test: lead vs no } \\
\text { lead model }\end{array}$} \\
\hline Chi 2 & 2.12 & 1.91 & 0.56 & 0.32 & 0.00 & 0.04 \\
\hline Prob & 0.145 & 0.168 & 0.454 & 0.573 & 0.955 & 0.850 \\
\hline \multicolumn{7}{|c|}{ ONE LAG AND ONE LEAD INTERACTED WITH A DUMMY FOR ADVANCE ANNOUNCEMENT } \\
\hline KAITZ_lead $1 * A D$ & 0.027 & 0.034 & 0.064 & -0.000 & 0.029 & 0.032 \\
\hline & $(0.021)$ & $(0.027)$ & $(0.040)$ & $(0.016)$ & $(0.033)$ & $(0.043)$ \\
\hline \multirow[t]{2}{*}{ KAITZ } & -0.012 & 0.005 & 0.070 & -0.085 & 0.068 & 0.093 \\
\hline & $(0.070)$ & $(0.094)$ & $(0.182)$ & $(0.055)$ & $(0.092)$ & $(0.117)$ \\
\hline \multirow[t]{2}{*}{ KAITZ_lag1 } & 0.072 & 0.120 & 0.202 & -0.023 & -0.070 & -0.080 \\
\hline & $(0.069)$ & $(0.094)$ & $(0.137)$ & $(0.055)$ & $(0.103)$ & $(0.119)$ \\
\hline $\mathrm{R} 2$ & 0.09 & 0.09 & 0.04 & 0.09 & 0.19 & 0.14 \\
\hline \multicolumn{7}{|l|}{$\begin{array}{l}\text { LR test: lead vs no } \\
\text { lead model }\end{array}$} \\
\hline Chi 2 & 1.53 & 2.97 & 2.05 & 0.00 & 0.78 & 0.64 \\
\hline Prob & 0.216 & 0.085 & 0.152 & 0.995 & 0.376 & 0.425 \\
\hline
\end{tabular}

Note: The number of observations is fixed at 1580 in all regressions. The results are obtained using the fixedeffects estimator. The table only reports the key variables of interest. Control variables that are not shown include: a dummy for partial coverage of the regional minimum wage, a dummy for the regional minimum wage being linked to the regional subsistence minimum, a dummy for discrepancies among different data sources regarding the regional minimum wage, and time effects (set of dummies for years and quarters). Cluster-robust standard errors with clustering on regions are reported in parentheses. Asterisks ***, **, * denote significance at the $1 \%, 5 \%$, and $10 \%$ levels, respectively. 
Appendix. Table A2. Choosing the lag and lead structure for the sub-sample, 2007-2010.

\begin{tabular}{|c|c|c|c|c|c|c|}
\hline & 1 & 2 & 3 & 4 & 5 & 6 \\
\hline & $\begin{array}{c}\text { UNEMPL } \\
15-72\end{array}$ & $\begin{array}{c}\text { UNEMPL } \\
25-72\end{array}$ & $\begin{array}{c}\text { UNEMPL } \\
15-24\end{array}$ & $\begin{array}{l}\text { UNEMPL } \\
\text { FEMALE }\end{array}$ & $\begin{array}{c}\text { INFORML } \\
\text { A }\end{array}$ & $\begin{array}{c}\text { INFORML } \\
\text { B }\end{array}$ \\
\hline \multicolumn{7}{|c|}{ NO LAGS } \\
\hline \multirow[t]{2}{*}{ KAITZ } & -0.023 & -0.012 & -0.037 & -0.011 & 0.024 & 0.022 \\
\hline & $(0.027)$ & $(0.022)$ & $(0.046)$ & $(0.021)$ & $(0.037)$ & $(0.049)$ \\
\hline $\mathrm{R} 2$ & 0.20 & 0.21 & 0.13 & 0.14 & 0.09 & 0.11 \\
\hline \multicolumn{7}{|c|}{ ONE LAG } \\
\hline \multirow[t]{2}{*}{ KAITZ } & -0.033 & -0.016 & $-0.083 *$ & -0.013 & -0.009 & -0.012 \\
\hline & $(0.028)$ & $(0.022)$ & $(0.044)$ & $(0.021)$ & $(0.035)$ & $(0.045)$ \\
\hline \multirow[t]{2}{*}{ KAITZ_lag1 } & $0.029 *$ & 0.011 & $0.133 * * *$ & 0.003 & $0.096 * * *$ & $0.100 * *$ \\
\hline & $(0.016)$ & $(0.015)$ & $(0.046)$ & $(0.014)$ & $(0.034)$ & $(0.043)$ \\
\hline $\mathrm{R} 2$ & 0.20 & 0.21 & 0.14 & 0.14 & 0.10 & 0.11 \\
\hline \multicolumn{7}{|c|}{ TWO LAGS } \\
\hline \multirow[t]{2}{*}{ KAITZ } & -0.031 & -0.015 & -0.070 & -0.011 & -0.009 & -0.015 \\
\hline & $(0.029)$ & $(0.023)$ & $(0.043)$ & $(0.022)$ & $(0.035)$ & $(0.045)$ \\
\hline \multirow[t]{2}{*}{ KAITZ_lag1 } & 0.022 & 0.010 & $0.085^{* *}$ & -0.001 & $0.098 * * *$ & $0.111 * * *$ \\
\hline & $(0.018)$ & $(0.019)$ & $(0.039)$ & $(0.015)$ & $(0.032)$ & $(0.040)$ \\
\hline \multirow[t]{2}{*}{ KAITZ_lag2 } & 0.012 & 0.003 & $0.076^{*}$ & 0.007 & -0.004 & -0.017 \\
\hline & $(0.020)$ & $(0.018)$ & $(0.041)$ & $(0.014)$ & $(0.022)$ & $(0.026)$ \\
\hline R2 & 0.21 & 0.21 & 0.15 & 0.14 & 0.10 & 0.11 \\
\hline \multicolumn{7}{|c|}{ THREE LAGS } \\
\hline \multirow[t]{2}{*}{ KAITZ } & -0.025 & -0.010 & -0.056 & -0.008 & -0.009 & -0.014 \\
\hline & $(0.030)$ & $(0.024)$ & $(0.045)$ & $(0.022)$ & $(0.037)$ & $(0.046)$ \\
\hline \multirow[t]{2}{*}{ KAITZ_lag1 } & 0.018 & 0.007 & $0.077^{*}$ & -0.003 & $0.098 * * *$ & $0.110 * * *$ \\
\hline & $(0.019)$ & $(0.019)$ & $(0.040)$ & $(0.015)$ & $(0.032)$ & $(0.040)$ \\
\hline \multirow[t]{2}{*}{ KAITZ_lag2 } & -0.008 & -0.013 & 0.035 & -0.003 & -0.005 & -0.020 \\
\hline & $(0.018)$ & $(0.016)$ & $(0.038)$ & $(0.014)$ & $(0.022)$ & $(0.028)$ \\
\hline \multirow[t]{2}{*}{ KAITZ_lag3 } & $0.035 * *$ & $0.028 *$ & $0.075^{*}$ & 0.018 & 0.002 & 0.004 \\
\hline & $(0.017)$ & $(0.016)$ & $(0.043)$ & $(0.014)$ & $(0.031)$ & $(0.036)$ \\
\hline $\mathrm{R} 2$ & 0.21 & 0.21 & 0.15 & 0.14 & 0.10 & 0.11 \\
\hline \multicolumn{7}{|c|}{ FOUR LAGS } \\
\hline \multirow[t]{2}{*}{ KAITZ } & -0.024 & -0.010 & -0.055 & -0.007 & -0.007 & -0.012 \\
\hline & $(0.030)$ & $(0.024)$ & $(0.045)$ & $(0.022)$ & $(0.038)$ & $(0.047)$ \\
\hline \multirow[t]{2}{*}{ KAITZ_lag1 } & 0.018 & 0.007 & $0.076^{*}$ & -0.004 & $0.096 * * *$ & $0.109 * * *$ \\
\hline & $(0.019)$ & $(0.019)$ & $(0.040)$ & $(0.015)$ & $(0.032)$ & $(0.041)$ \\
\hline \multirow[t]{2}{*}{ KAITZ_lag2 } & -0.007 & -0.012 & 0.036 & -0.002 & -0.003 & -0.018 \\
\hline & $(0.018)$ & $(0.017)$ & $(0.038)$ & $(0.014)$ & $(0.023)$ & $(0.028)$ \\
\hline \multirow[t]{2}{*}{ KAITZ_lag3 } & 0.030 & 0.024 & 0.057 & 0.008 & -0.025 & -0.020 \\
\hline & $(0.019)$ & $(0.016)$ & $(0.042)$ & $(0.015)$ & $(0.033)$ & $(0.037)$ \\
\hline \multirow[t]{2}{*}{ KAITZ_lag4 } & 0.011 & 0.008 & 0.036 & 0.021 & $0.055^{*}$ & 0.049 \\
\hline & $(0.015)$ & $(0.016)$ & $(0.037)$ & $(0.013)$ & $(0.028)$ & $(0.031)$ \\
\hline R2 & 0.21 & 0.21 & 0.15 & 0.14 & 0.10 & 0.11 \\
\hline \multicolumn{7}{|l|}{ Lags: } \\
\hline AIC & 3 & 3 & 3 & 0 & 1 & 1 \\
\hline BIC & 0 & 0 & 1 & 0 & 1 & 1 \\
\hline
\end{tabular}

Note: The number of observations is fixed at 1264 in all regressions. The results are obtained using the fixedeffects estimator. The table only reports the key variables of interest. Control variables that are not shown include: a dummy for partial coverage of the regional minimum wage, a dummy for the regional minimum wage being linked to the regional subsistence minimum, a dummy for discrepancies among different data sources regarding the regional minimum wage, and time effects (set of dummies for years and quarters). Cluster-robust standard errors with clustering on regions are reported in parentheses. Asterisks ***, **, * denote significance at the $1 \%, 5 \%$, and $10 \%$ levels, respectively. 


\begin{tabular}{|c|c|c|c|c|c|c|}
\hline & 1 & 2 & 3 & 4 & 5 & 6 \\
\hline & $\begin{array}{l}\text { UNEMPL } \\
15-72\end{array}$ & $\begin{array}{l}\text { UNEMPL } \\
25-72\end{array}$ & $\begin{array}{l}\text { UNEMPL } \\
15-24\end{array}$ & $\begin{array}{l}\text { UNEMPL } \\
\text { FEMALE }\end{array}$ & $\begin{array}{c}\text { INFORML } \\
\text { A }\end{array}$ & $\begin{array}{c}\text { INFORML } \\
\text { B }\end{array}$ \\
\hline \multicolumn{7}{|c|}{ ONE LAG AND ONE LEAD } \\
\hline \multirow[t]{2}{*}{ KAITZ_lead1 } & -0.004 & 0.003 & 0.025 & -0.002 & -0.018 & -0.016 \\
\hline & $(0.016)$ & $(0.013)$ & $(0.033)$ & $(0.012)$ & $(0.024)$ & $(0.029)$ \\
\hline \multirow[t]{2}{*}{ KAITZ } & -0.031 & -0.017 & $-0.097 * *$ & -0.011 & 0.001 & -0.004 \\
\hline & $(0.026)$ & $(0.020)$ & $(0.041)$ & $(0.019)$ & $(0.038)$ & $(0.047)$ \\
\hline \multirow[t]{2}{*}{ KAITZ_lag1 } & $0.029 *$ & 0.012 & $0.136 * * *$ & 0.003 & $0.093 * * *$ & $0.098 * *$ \\
\hline & $(0.016)$ & $(0.015)$ & $(0.046)$ & $(0.014)$ & $(0.034)$ & $(0.043)$ \\
\hline R2 & 0.20 & 0.21 & 0.14 & 0.14 & 0.10 & 0.11 \\
\hline \multicolumn{7}{|l|}{$\begin{array}{l}\text { LR test: lead vs no } \\
\text { lead model }\end{array}$} \\
\hline Chi 2 & 0.06 & 0.05 & 0.57 & 0.03 & 0.46 & 0.25 \\
\hline Prob & 0.805 & 0.817 & 0.451 & 0.865 & 0.498 & 0.618 \\
\hline \multicolumn{7}{|c|}{ ONE LAG AND ONE LEAD INTERACTED WITH A DUMMY FOR ADVANCE ANNOUNCEMENT } \\
\hline \multirow[t]{2}{*}{ KAITZ_lead1*ADV } & 0.007 & 0.008 & 0.013 & 0.003 & 0.005 & 0.007 \\
\hline & $(0.010)$ & $(0.009)$ & $(0.018)$ & $(0.007)$ & $(0.013)$ & $(0.015)$ \\
\hline \multirow[t]{2}{*}{ KAITZ } & -0.028 & -0.010 & -0.073 & -0.010 & -0.005 & -0.007 \\
\hline & $(0.032)$ & $(0.026)$ & $(0.050)$ & $(0.024)$ & $(0.037)$ & $(0.046)$ \\
\hline \multirow[t]{2}{*}{ KAITZ_lag1 } & $0.030 *$ & 0.012 & $0.135 * * *$ & 0.004 & $0.096 * * *$ & $0.101 * *$ \\
\hline & $(0.016)$ & $(0.015)$ & $(0.046)$ & $(0.014)$ & $(0.034)$ & $(0.043)$ \\
\hline $\mathrm{R} 2$ & 0.21 & 0.21 & 0.14 & 0.14 & 0.10 & 0.11 \\
\hline \multicolumn{7}{|l|}{$\begin{array}{l}\text { LR test: lead vs no } \\
\text { lead model }\end{array}$} \\
\hline Chi 2 & 0.72 & 1.13 & 0.48 & 0.18 & 0.11 & 0.15 \\
\hline Prob & 0.397 & 0.288 & 0.490 & 0.668 & 0.738 & 0.702 \\
\hline
\end{tabular}

Note: The number of observations is fixed at 1264 in all regressions. The results are obtained using the fixedeffects estimator. The table only reports the key variables of interest. Control variables that are not shown include: a dummy for partial coverage of the regional minimum wage, a dummy for the regional minimum wage being linked to the regional subsistence minimum, a dummy for discrepancies among different data sources regarding the regional minimum wage, and time effects (set of dummies for years and quarters). Cluster-robust standard errors with clustering on regions are reported in parentheses. Asterisks $* * *, * *, *$ denote significance at the $1 \%, 5 \%$, and $10 \%$ levels, respectively. 